\title{
Regulation of vascular endothelial growth factor in prostate cancer
}

\author{
Simone de Brot ${ }^{1}$, Atara Ntekim ${ }^{1}$, Ryan Cardenas ${ }^{1}$, Victoria James ${ }^{1}$, Cinzia Allegrucci', \\ David M Heery $^{2}$, David O Bates ${ }^{3}$, Niels $\varnothing$ dum $^{4}$, Jenny L Persson ${ }^{5}$ and Nigel P Mongan ${ }^{1,6}$ \\ ${ }^{1}$ Faculty of Medicine and Health Sciences, School of Veterinary Medicine and Science, University of Nottingham, \\ Sutton Bonington Campus, Nottingham LE12 5RD, UK \\ ${ }^{2}$ Department of Pharmacology, School of Pharmacy, University of Nottingham, Nottingham NG7 2RD, UK \\ ${ }^{3}$ Cancer Biology, Division of Cancer and Stem Cells, School of Medicine, University of Nottingham, Nottingham, UK \\ ${ }^{4}$ Department of International Health, Immunology and Microbiology, University of Copenhagen, \\ Copenhagen, Denmark \\ ${ }^{5}$ Clinical Research Center, Lund University, Malmö, Sweden \\ ${ }^{6}$ Department of Pharmacology, Weill Cornell Medical College, New York, New York 10065, USA
}

Correspondence

should be addressed

to N P Mongan

Email

nigel.mongan@

nottingham.ac.uk

\begin{abstract}
Prostate cancer ( $\mathrm{PCa}$ ) is the most common malignancy affecting men in the western world. Although radical prostatectomy and radiation therapy can successfully treat PCa in the majority of patients, up to $\sim 30 \%$ will experience local recurrence or metastatic disease. Prostate carcinogenesis and progression is typically an androgen-dependent process. For this reason, therapies for recurrent PCa target androgen biosynthesis and androgen receptor function. Such androgen deprivation therapies (ADT) are effective initially, but the duration of response is typically $\leq 24$ months. Although ADT and taxane-based chemotherapy have delivered survival benefits, metastatic PCa remains incurable. Therefore, it is essential to establish the cellular and molecular mechanisms that enable localized PCas to invade and disseminate. It has long been accepted that metastases require angiogenesis. In the present review, we examine the essential role for angiogenesis in PCa metastases, and we focus in particular on the current understanding of the regulation of vascular endothelial growth factor (VEGF) in localized and metastatic PCa. We highlight recent advances in understanding the role of VEGF in regulating the interaction of cancer cells with tumor-associated immune cells during the metastatic process of PCa. We summarize the established mechanisms of transcriptional and post-transcriptional regulation of VEGF in PCa cells and outline the molecular insights obtained from preclinical animal models of PCa. Finally, we summarize the current state of anti-angiogenesis therapies for PCa and consider how existing therapies impact VEGF signaling.
\end{abstract}

\section{Key Words \\ - angiogenesis \\ - animal model \\ - androgen \\ - castration-resistant prostate cancer \\ - neuroendocrine \\ - transcription \\ - xenograft}

\section{Prostate cancer: the molecular mechanisms of carcinogenesis and the role of androgens}

Prostate cancer ( $\mathrm{PCa}$ ) is the most common malignancy affecting western men (Ferlay et al. 2013, Siegel et al. 2015), and it is estimated to account for more than 220000 new cases and 27000 deaths in the USA in 2015. Advances in early diagnosis (Carter et al. 2013, Heidenreich et al. 2013), surgical, radio-, chemo-, and immunotherapies (reviewed in Lorente \& De Bono (2014) and Stewart \& Boorjian (2014)) are improving patient survival. However, the aging demographics of western countries suggest that PCa will remain a leading cause of cancer-related mortality in men.

Published by Bioscientifica Ltd. 
Although $>90 \%$ of PCa cases are diagnosed as androgenresponsive acinar adenocarcinoma (Humphrey 2012), the disease is clinically heterogeneous. Indeed, it is currently not possible to accurately distinguish high-risk prostate tumors, which require extensive therapeutic intervention, from low-risk indolent tumors, many of which do not require any therapy (Draisma et al. 2009, Cuzick et al. 2014, Tombal et al. 2014, Weiner et al. 2015). Therefore, most men with clinically localized PCa undergo radical prostatectomy or radiotherapy with curative intent (Boorjian et al. 2012, Heidenreich et al. 2014). Yet, it has been estimated that between 20 and 30\% of cases will experience recurrence (Boorjian et al. 2012). Following local recurrence and metastasis, androgen deprivation therapy (ADT), which is achieved medically or through orchiectomy, is typically effective for $<24$ months, by which time progression to the more detrimental form of castrateresistant PCa (CRPC) is common (Ahmed et al. 2014). At that point, PCa becomes hormone refractory, and cancer cells acquire the ability to invade and metastasize to lymph nodes and distant organs (Wegiel et al. 2005).

The importance of androgen signaling in prostate carcinogenesis has long been recognized (Huggins \& Hodges 1941). In the intervening decades, it became apparent that androgen signaling plays an essential role in localized and metastatic PCa (Wang et al. 2009). The androgen receptor (AR) is a member of the liganddependent transcription factor family of nuclear receptors, which also includes the estrogen (ER $\alpha / \mathrm{ER} \beta)$ and progesterone (PR) receptors, lipophilic ligands (retinoids, vitamin D), and orphan receptors for which ligands have not been identified. In the presence of an agonist, nuclear receptors regulate gene expression by recruiting epigenetic coregulator proteins with histone lysine acetyltransferase (KAT), methyltransferase (KMT), and demethylase (KDM) activity. Consistent with the essential role played by androgens and the AR in hormone-dependent (Yu et al. 2010) and refractory PCa (Wang et al. 2009), nuclear receptor coregulators have also been implicated in prostate carcinogenesis and progression (Debes et al. 2003, Rahman et al. 2003, Heemers et al. 2007). KDMs are key coregulators of $\mathrm{AR}$ and ER transcriptional activation and repression (Cheng \& Blumenthal 2010, Kooistra \& Helin 2012). A subset of KDMs, including KDM1A/LSD1, are overexpressed in PCa (Metzger et al. 2005, Kahl et al. 2006, Kashyap et al. 2013). Although KDM1A acts predominantly as a transcriptional corepressor, it can act as a coactivator for AR (Metzger et al. 2005) and ER $\alpha$ (Perillo et al. 2008), depending on promoter context (Cai et al. 2011). Consistent with this, there is evidence that KDM1A can contribute to hormone refractory PCa by sensitizing prostate cells to lower androgen levels (Cai et al. 2011, 2014). ARs and ERs are known to cooperate in gene regulation in PCa and can define transcriptional signatures associated with aggressive disease (Setlur et al. 2008). As we discuss in detail later in the present review, KDM1A appears to promote PCa recurrence in part by enhancing androgen-regulated VEGF expression (Kashyap et al. 2013). With a clear clinical need for new treatments, nuclear receptor epigenetic coregulators and related proteins are attractive therapeutic targets because of their feasibility as 'druggable' targets (Dawson \& Kouzarides 2012, Asangani et al. 2014, Rotili et al. 2014). For this reason, recently identified coregulator components of the AR-signaling complex represent potential new targets for circumventing resistance to existing therapies.

ADTs are the standard treatment for locally advanced and metastatic PCa. ADT targets AR signaling pathways, which are central to the gene expression programs that drive prostate tumor growth and metastasis. AR signaling persists in hormone refractory PCas that are resistant to ADT (Wang et al. 2009). Although ADTs impede tumor progression, hormone refractory cancers bypass androgen dependency and remain incurable. Recently introduced CRPC therapies include abiraterone, an inhibitor of a key enzyme in androgen biosynthesis, and the potent AR antagonist enzalutamide. Although both abiraterone and enzalutamide have demonstrated survival benefits in the CRPC context, the duration of response to these agents remains disappointing (de Bono et al. 2011, Scher et al. 2012). Furthermore, one consequence of prolonged systemic androgen blockade is the increasing emergence of neuroendocrine (NE) PCa, which is associated with aggressive disease and poor prognosis (Beltran et al. 2011). Although we now have unparalleled insight into the genomic complexity of PCa (Berger et al. 2011, Barbieri et al. 2012, 2013, Baca et al. 2013), there is therefore an urgent need to exploit this knowledge with a view to identifying novel approaches to prevent or delay PCa metastases.

\section{Transcriptional regulation of pro-angiogenesis pathways in PCa}

Pro-angiogenic pathways are essential mediators of tumor growth and metastasis, and as a consequence, the potential for therapies that target the tumor vasculature has long been recognized (Folkman 1971, Folkman et al. 1971). Both normal and pathologic angiogenesis is regulated predominantly by the vascular endothelial

Published by Bioscientifica Ltd 
growth factors (VEGFA, VEGFB, VEGFC, and VEGFD) and their cognate cell surface receptors (VEGFR1, VEGFR2, and VEGFR3), which can also be activated by neuropilins (Roskoski 2007). VEGF isoforms exhibit distinct receptor affinities and activate the intracellular receptor tyrosine kinase signaling cascade. The VEGFs and their receptors also play a role in PCa lymphangiogenesis (Wong et al. 2005, Burton et al. 2008). In the present review, we focus on the regulation and function of VEGFA (also referred to as simply VEGF) in angiogenesis. VEGF is overexpressed in a variety of hematological malignancies (Krejsgaard et al. 2006) and the vast majority of solid tumors, including PCa (Wegiel et al. 2005) (Fig. 1), where it is associated with poorer outcomes (Duque et al. 1999, Green et al. 2007). In $\mathrm{PCa}$, in addition to its expression in blood and lymphatic endothelial cells, VEGF is also expressed at low levels in prostatic glandular epithelial cells and in nonvascular cells, such as macrophages, fibroblast cells, and mast cells (Hrouda et al. 2003). Chronic prostatic inflammation and the infiltration of macrophages and other immune cells that express high levels of VEGF are believed to be important events during the malignant transformation. The increased production of cytokines, such as interleukin-6, is believed to induce VEGF expression in the infiltrating immune cells (Cohen et al. 1996). It has been shown that bacterial lipopolysaccharide induces the
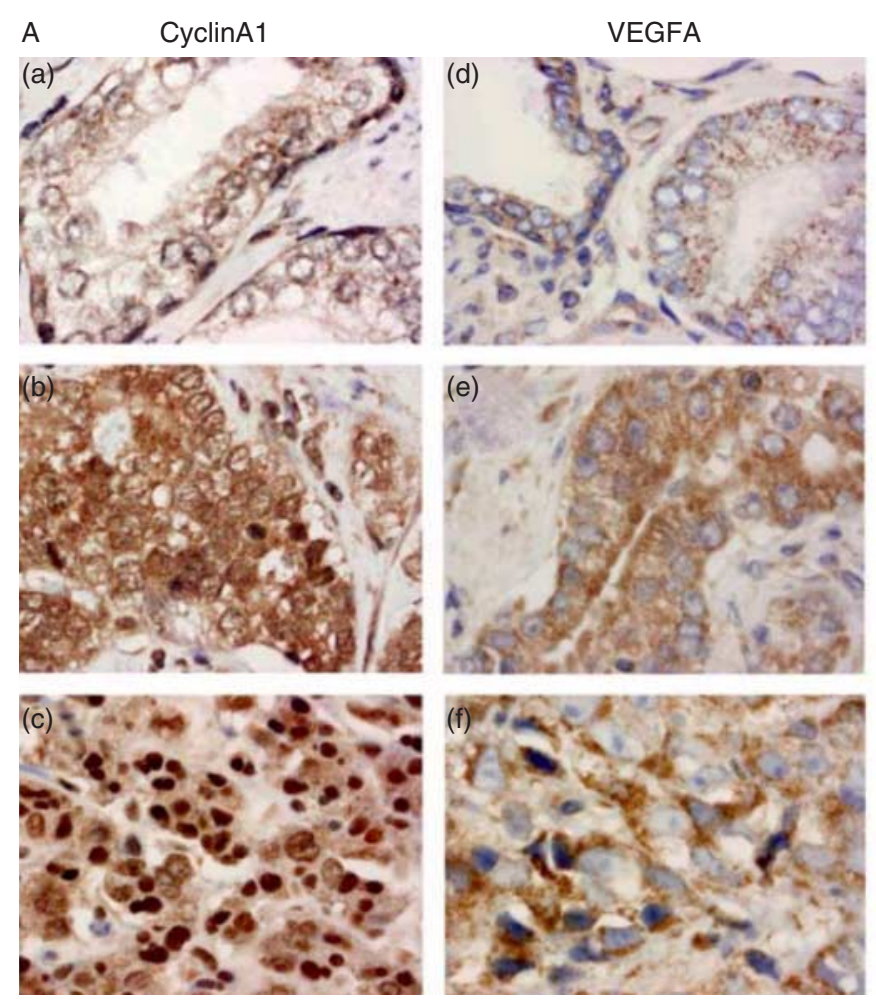
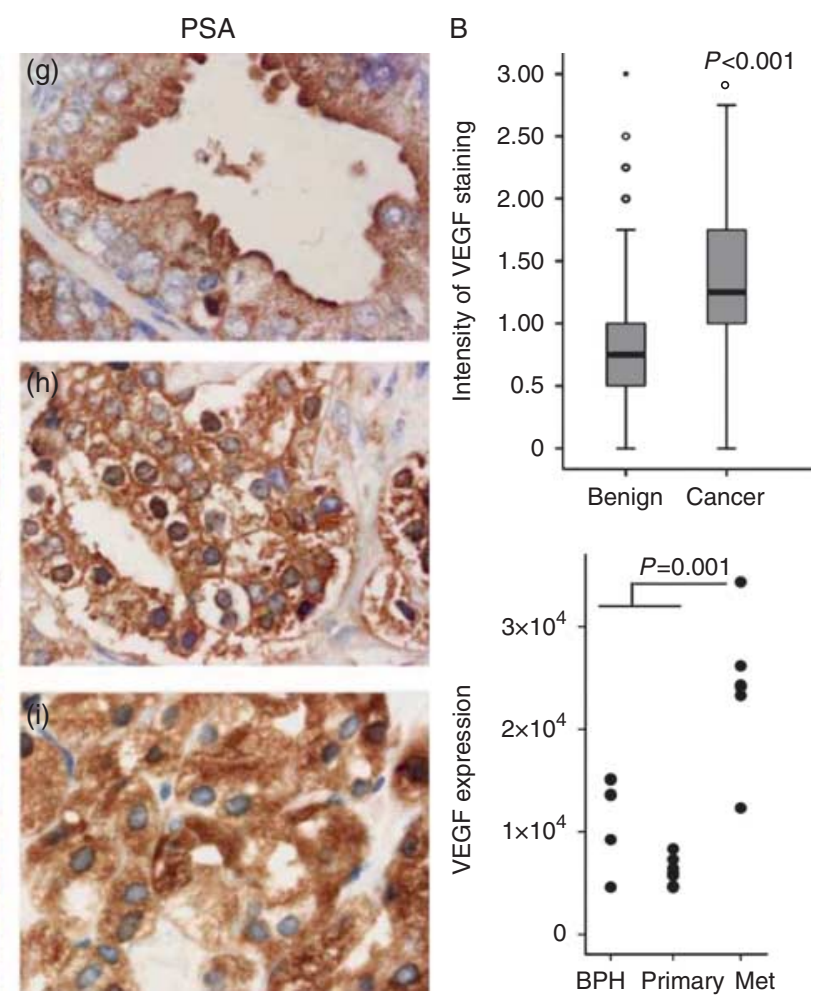

\section{Figure 1}

(A) Immunohistochemical analysis of the expression of cyclin A1 ( $a, b$ and c), vascular endothelial growth factor (VEGF) ( $d$, e and $f$ ) and prostate-specific antigen (PSA) ( $c, f$ and $i)$ in benign prostate hyperplasia $(a, d$ and $g$ ) and moderately ( $b$, e and $h$ ) and poorly differentiated $(c, f$ and i) prostate cancer (PCa) specimens. Adapted and reproduced, with permission from Macmillan Publishers Ltd: Oncogene, from Wegiel B, Bjartell A, Ekberg J, Gadaleanu V, Brunhoff C \& Persson JL 2005 A role for cyclin A1 in mediating the autocrine expression of vascular endothelial growth factor in prostate cancer. Oncogene 24 6385-6393, copyright 2005. (B) Evaluation of VEGF in PCa specimens. Tissue microarrays of sections from benign tissue and adjacent tumor tissue designated as Gleason grade $3(81 \%)$ or Gleason grades $4-5$ $(18 \%)$ were immunostained with antibodies against VEGF. Differences in the expression of VEGF (tumor, $n=864$; benign, $n=787$ ), between groups were assessed using the paired Wilcoxon signed rank test $(P<0.001)$. The mean values of intensities of staining (horizontal lines) with error bars representing $95 \% \mathrm{Cls}$ for the mean are shown. The outliers are labeled by open circles. The boxes represent the distribution of the expression of each protein in the group. The dot plot shows the expression of genes encoding VEGF in tumor specimens from patients with $\mathrm{BPH}(n=6)$, primary PCa $(n=7)$, and metastatic PCa (Met, $n=6$ ), as analyzed by CDNA microarray. Differences between metastatic cancers (Met) and nonmetastatic disease (benign PCa and primary tumors in localized cancer) were assessed by the Mann-Whitney $U$ test. $P$ values from two-sided tests are indicated. Adapted and reproduced, with permission from Oxford University Press, from Wegiel B, Bjartell A, Tuomela J, Dizeyi N, Tinzl M, Helczynski L, Nilsson E, Otterbein L, Härkönen P \& Persson JL. 2008 Multiple cellular mechanisms related to cyclin A1 in prostate cancer invasion and metastasis. Journal of the National Cancer Institute 100 1022-1036, copyright 2008.

Published by Bioscientifica Ltd 
expression of Toll-like receptors (TLRs) in human prostate epithelial PC3 cells after exposure to bacterial infection. This increased expression of TLRs is able to induce VEGF expression, which in turn triggers the proliferation and migratory ability of PCa cells (Pei et al. 2008).

The VEGF promoter is regulated by multiple transcription factor complexes, and the function of the hypoxiainducible factors in the regulation of VEGF expression is well understood (Forsythe et al. 1996, Gray et al. 2005). However, over the past decade, it has become apparent that the VEGF promoter can be regulated by multiple members of the nuclear receptor family, including the AR (Eisermann et al. 2013), estrogen (ER $\alpha / \mathrm{cMyc})$ (ButeauLozano et al. 2002, Dadiani et al. 2009), progesterone
(Wu et al. 2004), vitamin D (Cardus et al. 2009), and the liver-X receptors (Walczak et al. 2004). Consistent with this, animal studies have indicated a role for androgens and estrogen in prostate vascularization (Daehlin et al. 1985). In this context, it is interesting to note that nuclear receptor-coregulator complexes can regulate splicing events (Auboeuf et al. 2002, 2004). Thus, a role for the aberrant recruitment of nuclear receptor complexes to the $V E G F$ promoter in the induction of pro-angiogenic VEGF splicing during carcinogenesis cannot be excluded (Fig. 2).

Interestingly, recent studies have identified pro- and anti-angiogenic VEGF splice forms (Bates et al. 2002), which are differentially regulated in cancers, including in PCa (Woolard et al. 2004, Mavrou et al. 2014), and which

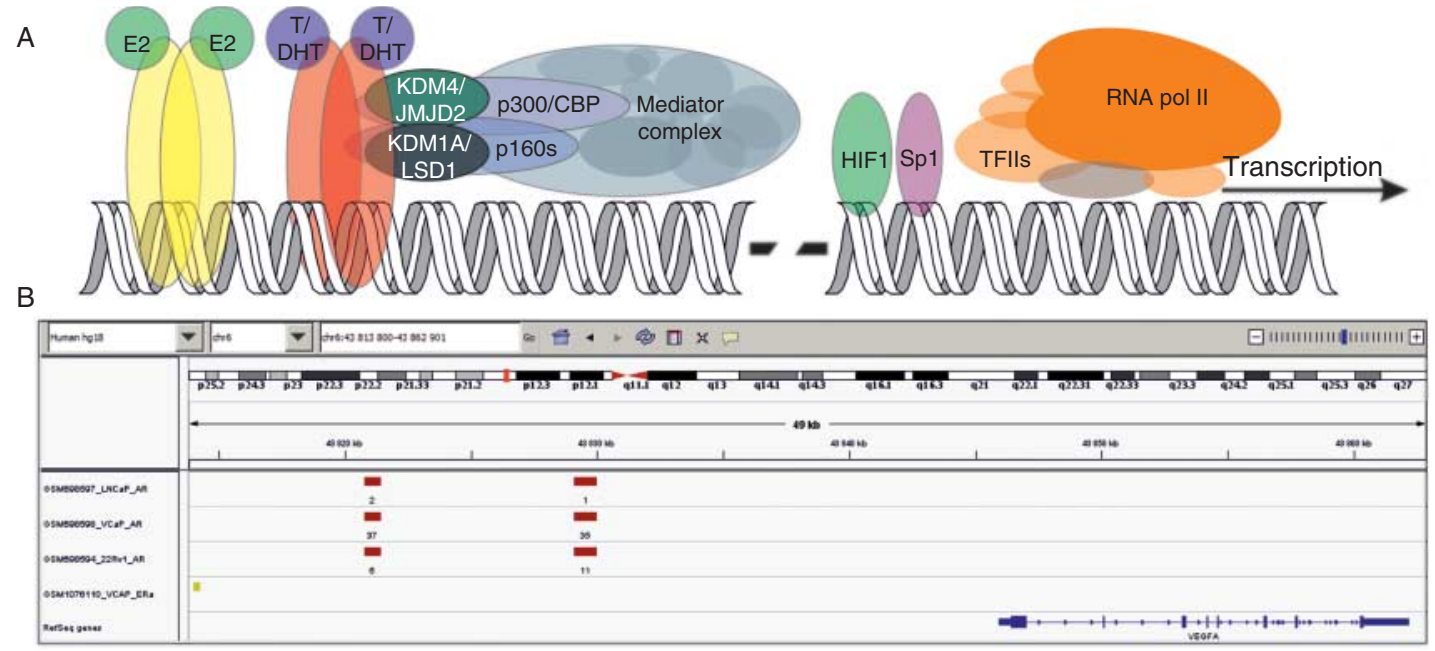

C

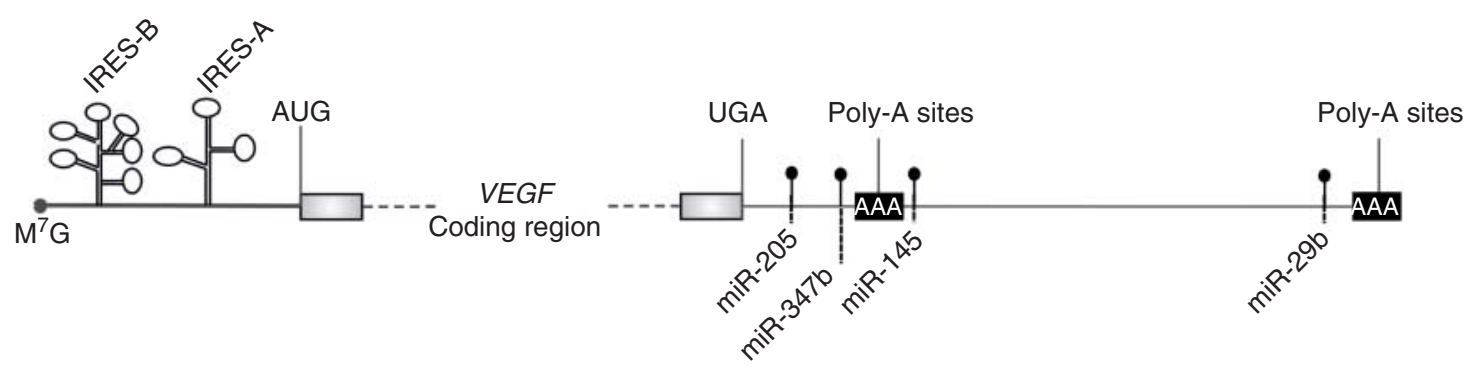

\section{Figure 2}

(A) The VEGF promoter is regulated by a diverse array of transcription factors, hypoxia-inducible factors (HIFs), specificity protein-1 (Sp1), and most notably in the context of the present review, multiple nuclear receptors, including androgen (Eisermann et al. 2013) and estrogen (Buteau-Lozano et al. 2002, Dadiani et al. 2009), which are indicated in red and yellow respectively. In addition, the VEGF promoter is regulated by progesterone (Wu et al. 2004), vitamin D (Cardus et al. 2009), and the liver$X$ nuclear receptors (LXR) (Walczak et al. 2004). Nuclear receptors recruit multiple enzymatically diverse epigenetic coregulators, including p160/p300 lysine acetyltransferase, demethylases that cooperate with the mediator complex to stabilize recruitment of the basal transcriptional machinery, and RNA polymerase II. (B) Evidence from genome-wide chromatin immunoprecipitation studies indicate the recruitment of $A R$ in LNCaP, 22Rv1, VCaP PCa cells (GSM698597) (Sharma et al. 2013), and ER $\alpha$ in VCaP (GSM1076110) (Chakravarty et al. 2014) to the VEGF promoter. (C) Positions of microRNA target sites and internal ribosome entry sites (IRES) in relation to the coding sequence of the VEGF. 
may be key to the development of future therapies that target pro-angiogenic VEGF function (Harper \& Bates 2008). In the terminal exon of the VEGF gene (exon 8), there are two potential splice sites. A proximal splice site (PSS) encodes six amino acids (CDKPRR) before a stop codon is reached, which results in isoforms such as VEGFA $_{165}$ a. The use of the PSS results in the generation of angiogenic isoforms that increase vascular permeability, stimulate vessel growth, and result in vasodilatation. Further into the terminal exon, a distal splice site, 66 bases downstream of the PSS, results in an alternative open reading frame of the same size (six amino acids, SLRTKD), which in turn results in a different $\mathrm{C}$-terminus to the protein. Furthermore, VEGFA ${ }_{165} \mathrm{~b}$ switches the protein to an anti-angiogenic one that can inhibit vasodilatation (Woolard et al. 2004) and reduce permeability (Oltean et al. 2012). The splice variants are differentially regulated (e.g., SRPK1 stimulates splicing to VEGFA ${ }_{165} \mathrm{a}$, and Clk1/4 stimulates splicing to $\mathrm{VEGFA}_{165}$ b) (Nowak et al. 2008, 2010) and are differentially regulated post-transcriptionally - for example, by T-cell intracellular antigen-1, an RNA-binding protein that differentially regulates translation and splicing of VEGF through activation by Ras (Hamdollah Zadeh et al. 2015).

\section{Post-transcriptional regulation of VEGF signaling in $\mathrm{PCa}$}

Regulation of VEGF expression can occur at multiple points between transcription and translation. These regulatory effects broadly fall into three different areas: pre-mRNA processing (alternative splicing, as discussed in the previous section), mRNA transcript stability, and control of translation. The latter two categories are discussed in the present section, with a focus on the mechanisms of VEGF post-transcriptional regulation in PCa.

Variations in mRNA transcript stability are commonly seen as cellular responses to environmental changes, such as stress and nutrient availability; they act as rapid responses in order to maintain protein homeostasis. $V E G F$ is tightly regulated at the transcript level, and although its reported half-life is short (15-40 min in vitro), this can be substantially extended during periods of hypoxia and nutrient withdrawal (Ikeda et al. 1995, Shima et al. 1995, Levy et al. 1996, Dibbens et al. 1999). AU-rich elements within the $3^{\prime}$ UTR of the VEGF transcript, along with other elements within the coding and UTRs, are potential targets for a range of RNA-binding proteins that have been shown to result in both positive and negative effects on transcript stability (Claffey et al. 1998,
Shih \& Claffey 1999, King 2000, Goldberg-Cohen et al. 2002, Coles et al. 2004, Onesto et al. 2004, Fellows et al. 2012, Chang et al. 2013). Hypoxia-dependent regulation of transcript stability has been well characterized in a number of cancer types and was recently reviewed by Arcondeguy et al. (2013).

Interestingly, two less well-characterized methods of hypoxia-independent regulation of VEGF transcript stability have been observed in studies of PCa. The first occurred when DU145 PCa cells were subjected to glucose deprivation. Under these conditions, VEGF transcript stability was increased as a result of the stimulation of AMP-activated protein kinase through a mechanism that is still unknown (Yun et al. 2005). In addition to this, an isoform of the Wilms' tumor suppressor gene (WT1-A) was found to modestly increase VEGF transcript stability in a hormone-enhanced mechanism when $W T 1$ was stably overexpressed in LNCaP PCa cells. Overexpression of other WT1 isoforms the lacked the third of fourth zinc finger domains was unable to mediate VEGF stability, which indicates the potential importance of zinc finger domains in this regulatory mechanism (Cash et al. 2007).

Eukaryotic protein translation predominantly depends on the $\mathrm{m}^{7} \mathrm{G}$ cap structure of the mRNA and assembly of the translation initiation complex (cap-dependent translation). However, alternative mechanisms of cap-independent translation have evolved in order to maintain or activate the translation of essential proteins during periods of cellular stress when cap-dependent translation is impaired (reviewed by Van Der Kelen et al. (2009)). Cap-independent mechanisms depend on the presence of internal ribosome entry sites (IRES) to enable the initiation of translation. Although they were originally identified in viruses, multiple eukaryotic mRNAs, including VEGFs, have also been reported to contain IRES sequences (Jang et al. 1988, Pelletier \& Sonenberg 1988). The VEGF mRNA 5'UTR features two IRESs: IRES-A and IRES-B, 293 and 947 nucleotides upstream of the canonical AUG start site respectively; the position of IRES-B is also slightly more than 40 nucleotides upstream of an alternative CUG start codon (Akiri et al. 1998, Huez et al. 1998, Miller et al. 1998). A single-nucleotide polymorphism (SNP) of the VEGF gene ( $-634 \mathrm{C}>\mathrm{G}$ substitution) has been linked with an increased risk of PCa (Sfar et al. 2006). This SNP was found to impair IRES-B function by reducing translation initiated from the alternative CUG start codon (Lambrechts et al. 2003). Furthermore, a 17-nucleotide sequence within VEGF IRES-A has been shown to promote the formation of an intramolecular G-quadruplex structure (Morris et al. 2010). G-quadruplex formation potentially regulates

Published by Bioscientifica Ltd. 
multiple aspects of RNA regulation, in the case of VEGF, mutations of this 17-nucleotide sequence prevent G-quadruplex formation and result in the inhibition of IRES-A function (Morris et al. 2010). The contribution of G-quadruplex regulation to VEGF expression in PCa remains to be determined, but given the role of IRESs in mediating VEGF translation under stress conditions, these intramolecular structures warrant further investigation.

The translation efficiency of VEGF can be further modified by microRNAs (miRNAs), a class of small, noncoding RNA. miRNAs regulate translation by binding to specific sequences within the target mRNA. Usually these binding sites reside within the $3^{\prime} \mathrm{UTR}$, but they can also occur in the $5^{\prime} \mathrm{UTR}$ and coding regions (Tay et al. 2008). Target binding is mediated by the miRNA-associate RNA-induced silencing complex and results in either the repression of translation or mRNA degradation, with the net result of both processes being reduced protein expression (reviewed by Huntzinger \& Izaurralde (2011)). Analyses of prostate tissue and cell lines have identified multiple miRNAs, the expressions of which are consistently being altered in prostate tumors, which has led to further analysis of downstream gene targets and their potential contribution to carcinogenesis. Szczyrba et al. (2010, 2013) reported a significant reduction of miR-29b expression in $\mathrm{PCa}$ and subsequently demonstrated miR-29b as a direct regulator of VEGF in PCa cell lines LNCaP and DU145.

In addition to miR-29b, the VEGF transcript is predicted to contain binding sites for multiple miRNA types (as highlighted in Fig. 2C), such as miR-145 and miR-205, the expressions of which are reduced in PCa and have been shown to regulate VEGF in other cancer types (Szczyrba et al. 2010, Fan et al. 2012, Yue et al. 2012, Boll et al. 2013). However, it remains to be determined how effectively these miRNAs repress VEGF translation in PCa. Indeed, it is also possible that such repression may only occur in specific cellular contexts. In relation to this point, an investigation of the anti-angiogenic effects of melatonin on hypoxic PCa PC3 cells identified a melatonindependent increase in the expression of miR-374b. Subsequent studies confirmed that miR-374b mediated the anti-angiogenic effects of melatonin by inhibiting VEGF expression (Sohn et al. 2015).

\section{VEGF signaling, bone metastasis, and niches}

The dissemination of cancer cells from the primary tumor site to distant organs is a key step during cancer progression. Once cancer cells invade into the bone, liver, and lungs, no curable treatment exists. PCa cells preferentially invade into the bone. It is estimated that $70 \%$ of patients with metastatic PCa develop bone metastasis (Shah et al. 2004, Semenas et al. 2012). These studies suggest that altered VEGF expression in endothelial cells leads to impaired blood vessel invasion. Because blood vessels serve as a way of transporting circulating cancer cells, the increased blood vessel beds will increase the transporting of cancer cells into the blood vessel-enriched organs, including the liver and lungs.

The spread of PCa cell metastasis to bone is a complex process that involves the local infiltration of tumor cells into adjacent tissue, migration from the primary tumor site into vessels (intravasation), survival and dissemination through the vascular system, extravasation, and finally, invasion and subsequent proliferation into the bone. There is increasing evidence showing that VEGF signaling plays an important role in promoting bone metastasis of PCa. It has been shown that VEGF signaling initiates metastatic niches to allow cancer cells to home to the bone marrow during bone metastasis (Kaplan et al. 2005). VEGF may stimulate the proliferation and migration of the infiltrated immune cells that secondarily infiltrate tumor tissue to promote PCa cells to enter into the blood vessels and to disseminate into distant organs. The expression of VEGF has also been detected in osteoblasts (Maes et al. 2010).

Previous reported studies have shown that VEGF has autocrine and paracrine effects on the growth and survival activity of osteoblasts (Midy \& Plouet 1994, Street et al. 2002, Dai et al. 2004). Furthermore, bone morphogenesis proteins contribute to $\mathrm{PCa}$-mediated osteoblastic activity in vitro partly through VEGF (Dai et al. 2004). It has also been shown that VEGF contributes to PCa-induced bone remodeling at bone metastatic sites in mouse models (Kitagawa et al. 2005). These studies suggest that the altered expression of VEGF in both PCa cells and cells of invaded bone tissue may result in the increased activity of bone cells, which leads to an imbalance of bone formation and resorption. VEGF is also functionally linked to adhesion molecules, such as fibronectin and extracellular matrix. These proteins may assist tumor cells to attract and adhere to the bone microenvironment through the VEGF receptors VEGFR1 and VEGFR2 (Chen et al. 2004, Sterling et al. 2011).

VEGF, in addition to its angiogenic role, suppresses the immune system (Fig. 3). It has been shown that VEGF directly or indirectly exerts multiple immunosuppressive activities. It has been reported that VEGF secreted by mouse tumor cells prevented dendritic cells from maturing, thereby hampering tumor antigen presentation

Published by Bioscientifica Ltd 


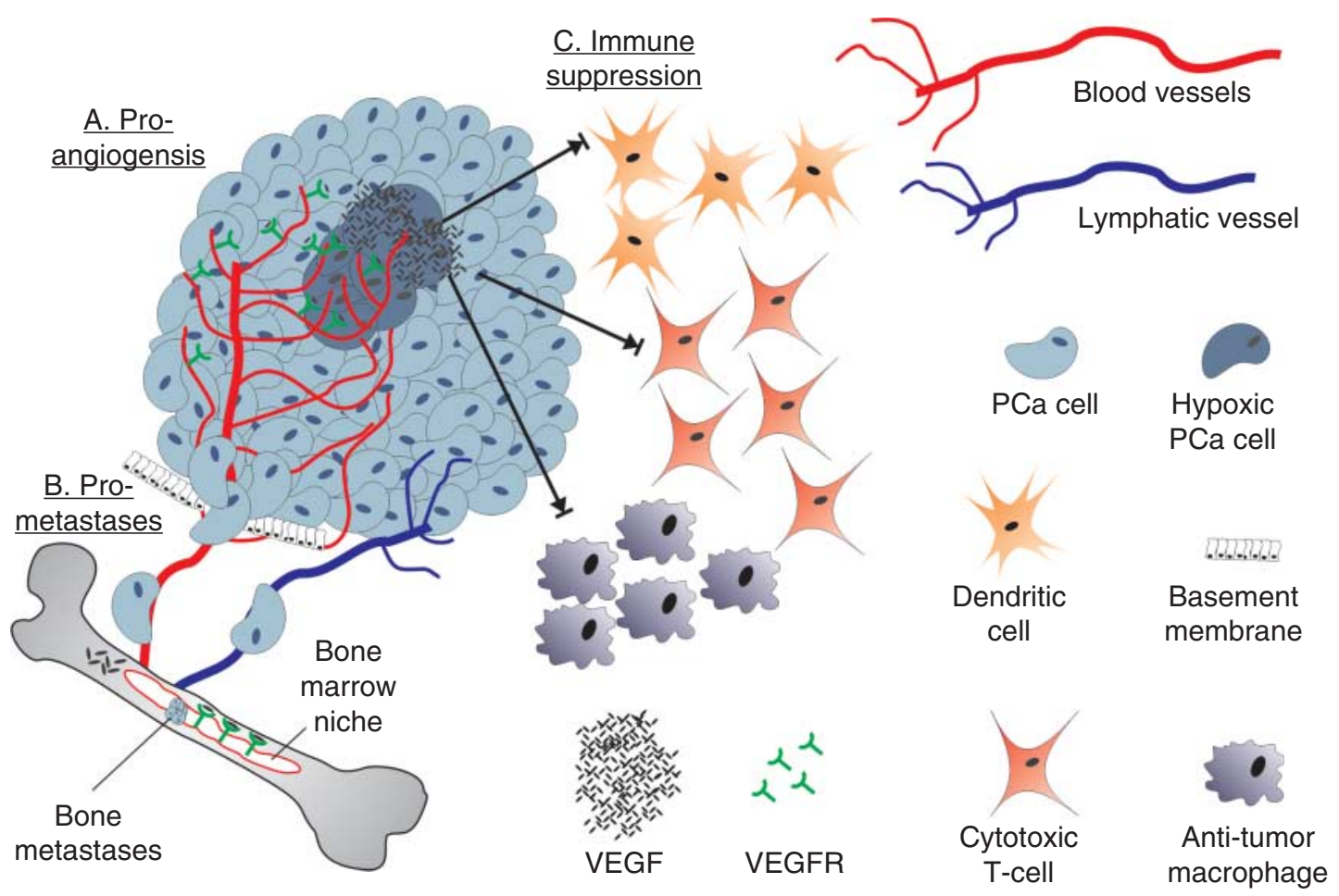

Figure 3

VEGF influences multiple convergent mechanisms that contribute to metastases. VEGF promotes angiogenesis in response to intratumoral hypoxia and deregulated hypoxia inducible factor function $(A)$, promotes local invasion and distant metastases by facilitating PCa cell colonization of

(Gabrilovich et al. 1996). VEGF expression is present in cytotoxic $\mathrm{T}$ cells, and it has been shown that increased expression of VEGF and VEGFR2 suppressed the activity of the T-cell receptor CD47 and cytotoxic T cell function (Kaur et al. 2014). Altered VEGF signaling may also suppress the function of dendritic cells and indirectly inhibit T-cell infiltration of tumor tissue. Consistent with this, VEGF blockade has resulted in increased T-cell homing to tumors and has enhanced the efficacy of immunotherapy in mouse models (Mellman et al. 2011; Fig. 4).

\section{Mouse models of $\mathrm{PCa}$ and relevant aspects of angiogenesis/VEGF signaling}

The need for a better understanding of the molecular and pathological events involved in PCa progression has driven the development of animal models. Animal models of PCa can be distinguished into two broad groups, the first being xenograft of human PCa into immunecompromised mice and the second being genetically modified mice that will develop prostatic cancer during their lifetime (Gingrich et al. 1999, Gray et al. 2004). niches within the bone marrow (B), and suppresses the function of cytotoxic T, anti-tumor macrophages and dendritic cells, which thereby enables disseminating tumor cells to evade immune surveillance (C).

Although they are informative, mouse models have several limitations. These include the inability to encompass the full complexity of the human disease and the inherent resistance to the development of invasive PCa. Nevertheless, several mouse models have been developed for the study of PCa, and these have been comprehensively reviewed elsewhere (Wu et al. 2013, Grabowska et al. 2014, Berman-Booty \& Knudsen 2015). In the present review, we focus on those that more closely recapitulate the progression of the human disease (Table 1).

Several xenograft animal models have been developed to recapitulate the progression of human PCa. The PC3 and LNCaP, which are derived from an osteolytic and a lymph node metastasis respectively, are two of the cell lines that are most frequently used to study PCa (Kaighn et al. 1979, Horoszewicz 1980). Several sublines were derived from these original cell lines with enhanced tumorigenicity in vivo, including LNCaP-Pro3-5, LNCaPLN3-4, PC3M, PC-3M-LN4 (Wu et al. 2013). LNCaP-LN3 and LNCaP-Pro5 xenografts are thought to resemble prostatic adenocarcinomas, because xenografts express $\mathrm{AR}$ and prostate-specific antigen (PSA) and are shown to

Published by Bioscientifica Ltd. 


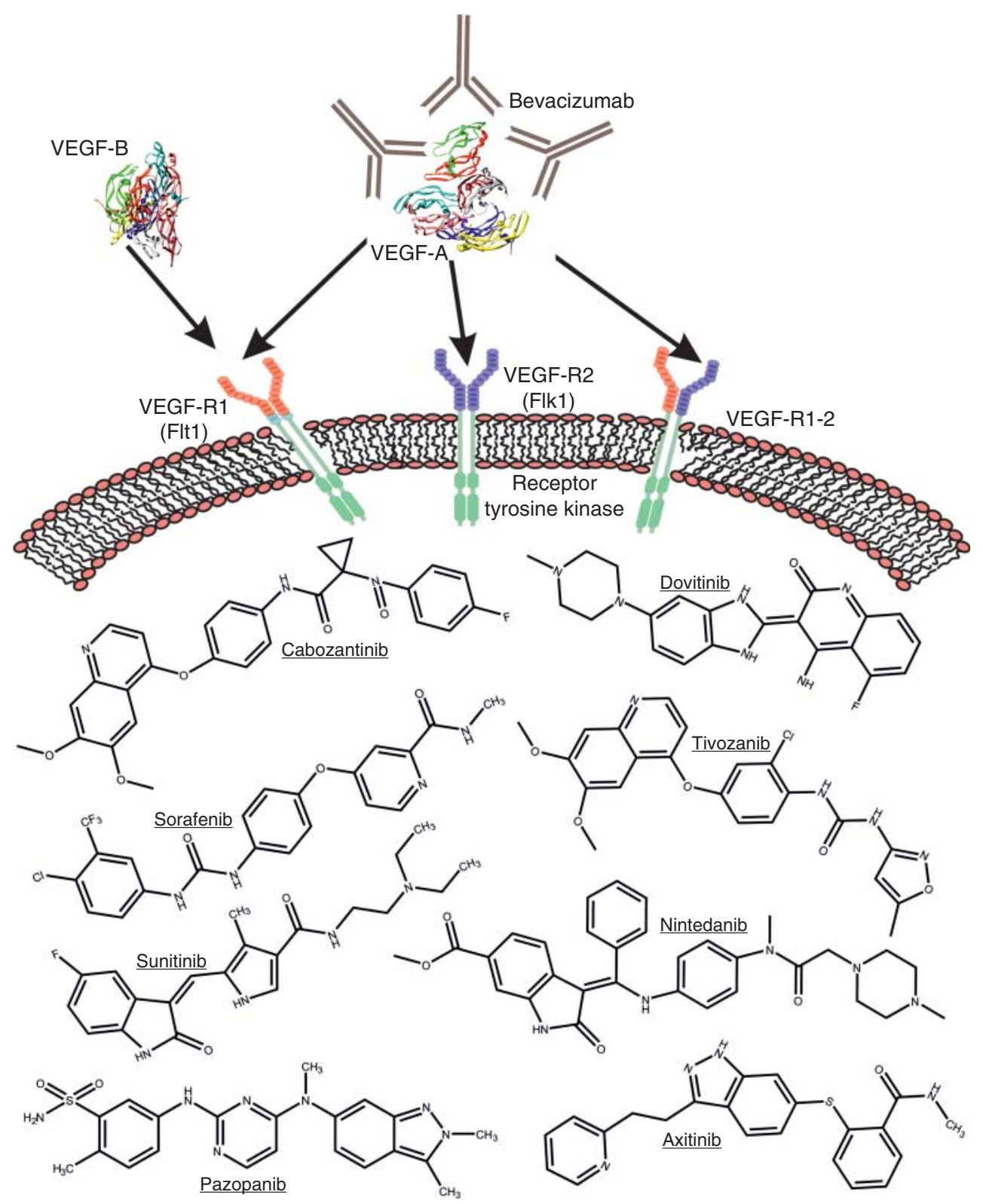

Figure 4

Therapies that target the receptor tyrosine (RTK) activity of VEGF receptors. Results have been disappointing for nintedanib (Molife et al. 2014). However, dovitinib (Wan, et al. 2014, Porta et al. 2015), cabozantinib (Smith et al. 2014), pazopanib (Sridhar et al. 2014), and axitinib (Eswaraka et al.

be androgen-sensitive (Pettaway et al. 1996, Yonou et al. 2001). I.v. or orthotopic injections of LNCaP in mice are able to metastasize to subcutaneously implanted human adult bone but not to murine bone (Yonou et al. 2001). Interestingly, one androgen-independent subline, LNCaP C4-2, is able to metastasize to the bone and cause osteoblastic lesions (Thalmann et al. 1994). PC3M xenografts are androgen-insensitive and stain negative
2014) have shown some promising activity in patient subsets in PCa clinical trials or preclinical models. The structures of the FDA-approved RTK inhibitors sorafenib and sunitinib are shown for comparison. Trials of tivozanib are under way (NCT01885949).

for PSA and AR, and the subline PC-3M-LN4 forms bone, lymphatic, and lung metastases after orthotopic or i.v. injection into mice (Pettaway et al. 1996, Yonou et al. 2001). Overall, these data suggest that LNCaP xenografts may model an earlier-stage PCa progression than PC3 xenografts do.

The WISH-PC2 xenograft model was derived from a poorly differentiated adenocarcinoma that was treated

Published by Bioscientifica Ltd 
Table 1 Selected mouse models for the study of prostate cancer (PCa) progression

\begin{tabular}{|c|c|c|c|c|c|}
\hline Model & PCa type & Metastasis & CRPC model & NE PCa model & VEGF studies \\
\hline \multicolumn{6}{|l|}{ Mouse xenografts } \\
\hline $\begin{array}{l}\text { LNCaP (Sublines: LNCaP-Pro3-5, } \\
\text { LNCaP-LN3-4, LNCaP-IL6, LNCap-abl, } \\
\text { LNCaP C4-2) }\end{array}$ & $A D, M C$ & $\mathrm{~V}, \mathrm{~L}$ & NR & No & Sweeney et al. (2002) \\
\hline $\begin{array}{l}\text { PC3 (Subline: PC3M, PC3-AR, } \\
\text { PC-3M-LN4, PC-3M-luc-C6, } \\
\text { PC-3M-Pro4) }\end{array}$ & $A D, M C$ & $\mathrm{~V}, \mathrm{~B}, \mathrm{~L}$ & Yes & No & $\begin{array}{l}\text { Anai et al. (2011) and } \\
\text { Pang et al. }(2011 a, b)\end{array}$ \\
\hline WISH-PC2 & $\mathrm{MC}, \mathrm{NE}$ & $V, L$ & Yes & Yes & NR \\
\hline LTL352, LTL370 & MC, NE & Yes, NR & Yes & Yes & NR \\
\hline \multicolumn{6}{|l|}{ Genetically engineered mice } \\
\hline TRAMP & $A D, N E$ & $V, B, L$ & Yes & Yes & Montico et al. (2014) \\
\hline LADY (12T-7s-f/PB-hepsin) & $\mathrm{MC}, \mathrm{NE}$ & $\mathrm{V}, \mathrm{B}$ & NR & Yes & NR \\
\hline LADY (12T-10) & $\mathrm{MC}, \mathrm{NE}$ & $V, B, L$ & NR & Yes & NR \\
\hline $\mathrm{P} 53^{\mathrm{PE}-1-} \mathrm{Rb}^{\mathrm{PE}-1-}$ & MC, NE & $\mathrm{V}, \mathrm{L}$ & Yes & Yes & NR \\
\hline Pten $^{\text {flox/flox }}$ & MC & $\mathrm{V}, \mathrm{L}$ & Yes & No & Geretti et al. (2010) \\
\hline Pten $^{\text {flox/flox NKX3.1-Cre }}{ }^{\text {ERT2 }}$ & $A D$ & $\mathrm{~L}$ & Yes & NR & NR \\
\hline 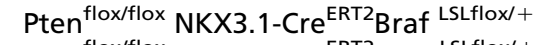 & $A D, M C$ & $V, L$ & NR & NR & NR \\
\hline Pten $^{\text {flox/flox NKX3.1-Cre }{ }^{\text {ERT2 }} \text { Kras }}{ }^{\text {LSLflox/+ }}$ & $A D, M C$ & $V, L$ & NR & NR & NR \\
\hline Pten ${ }^{\text {flox/flox }}$, Smad4 flox/flox & $\mathrm{MC}$ & $\mathrm{V}, \mathrm{L}$ & NR & NR & NR \\
\hline Z-Myc, Pten ${ }^{\text {flox } /+}, p 53^{\text {flox/flox }}$ & $A D, M C$ & $L, B$ & NR & No & NR \\
\hline
\end{tabular}

$A D$, adenocarcinoma; $M C$, metastatic carcinoma; $A l$, androgen independent; NE, neuroendocrine; CRPC, castrate-resistant prostate cancer ( $P C a)$; SQ, squamous differentiation; V, visceral; B, bone; L, lymph nodes; NR, not reported.

with androgen deprivation (AD) and was histologically consistent with a NE PCa upon implantation (Pinthus et al. 2000). WISH-PC2 orthotopic xenografts are able to metastasize to the lymph nodes, lungs, and liver, and when they are injected locally, they can form tumors within bone and liver tissues (Pinthus et al. 2000). Other NE PCa-relevant models include the LTL352 and LTL370, which are derived from metastatic NE PCa resected from urethral and penile areas respectively. Like WISH-PC2, these xenografts stain negative for PSA and AR, and they can grow in androgen-deprived mice with rapid doubling time. A major limitation of xenograft models is that most of the tissues are obtained from advanced and aggressive PCas, and they therefore tend to model later stages of the disease. Furthermore, one intrinsic limitation of xenografts is that these systems depend on the effective murine vascularization of human cancer cell masses, and they may therefore not fully recapitulate all aspects of tumors in patients. Nevertheless, the xenograft models, especially LNCaP xenografts, have been instrumental for understanding PCa and for many preclinical studies.

Transgenic mouse models can approximate the different stages of PCa progression, from low-grade to high-grade prostate intraepithelial neoplasia, adenocarcionoma, and metastatic cancer. Early models utilized the expression of viral oncogenes (such as small and large SV40 tumor antigens under the control of the prostate-specific probasin (PB) promoter) in the prostate epithelium. The viral oncogene models differ from human PCa, insofar as they present a rapid progression of the disease and predominant NE differentiation. However, they have been recognized as relevant models for $\mathrm{PCa}$, and they are very useful for the investigation of CRPC that progresses to NE carcinoma (Berman-Booty \& Knudsen 2015). In the transgenic adenocarcinoma mouse prostate (TRAMP) model, a rapid progression of PCa with lymph node and lung metastasis has also observed, and bone metastasis has only been reported for the FVB mouse background (Gingrich et al. 1996). The TRAMP mice have also responded to castration and progressed to hormone refractory disease associated with NE differentiation and increased metastasis rate (Gingrich et al. 1997, KaplanLefko et al. 2003). Similarly, some LADY mouse model lines (e.g., 12T-7s-f/PB-hepsin and 12T10) have been shown to drive invasive carcinoma and NE carcinoma with metastasis to the liver, lungs, and bone (Masumori et al. 2001, Klezovitch et al. 2004). The second-generation mouse models were based on human PCa genetic alterations and included a loss of the tumor-suppressor genes Pten, Nkx3.1, $p 53$, and $R b$ and amplification of the MYC oncogene. Interestingly, none of the single-gene deletion models shows a significant PCa phenotype, but their synergistic inactivation results in cancer onset. For instance, simultaneous inactivation of $p 53$ and $R b$ results in the formation of highly metastatic tumors that are resistant to castration and show NE differentiation (Zhou et al. 2006). The best of

Published by Bioscientifica Ltd 
these new models incorporate multiple genetic lesions with Cre-gene targeting. The most-utilized models are based on the conditional targeted deletion of PTEN, and they seem to recapitulate the disease progression seen in humans, including the development of CRPC with the activation of PI3K/Akt signaling (Wang et al. 2003, Grabowska et al. 2014).

Even though VEGF is the main angiogenic factor involved in PCa progression and metastasis, few studies have examined the role of VEGF in PCa animal models. Xenografts of $\mathrm{PCa}$ and benign prostate primary tissue exhibit maturation of vascularization at 30 days, when small vessels of human origin containing red blood cells become present (Presnell et al. 2001, Gray et al. 2004, Montecinos et al. 2012). At day 6 post-implantation into mice, these xenograft tumors exhibit a surge of angiogenesis, which is preceded by an up-regulation of VEGF in the stromal counterpart of the tumor at day 2 (Montecinos et al. 2012). A further increase in VEGF protein has also been shown to be modulated through the addition of human testosterone pellets implanted into castrated mice as compared to the controls (Montecinos et al. 2012). These data suggest a role for VEGF in angiogenesis establishment and $\mathrm{PCa}$ progression through androgen regulation. During $\mathrm{AD}$, a marked reduction in microvascular density was seen after 2 days, and it was followed by vascular reestablishment from days 7 to 14 (Godoy et al. 2011). The expression of VEGF and VEGFR2 increased in epithelial cells 2 days post-AD, which suggests a compensatory role for these molecules in the survival and progression of PCa (Godoy et al. 2011). These data suggest androgen-dependent and androgen-independent mechanisms for VEGF induction. As described earlier in the present review, most xenograft models use primary $\mathrm{PCa}$ tissue; however, PCa cell lines have been exploited in a subset of studies. For example, PC3 has been used to investigate the use of drugs to inhibit VEGF signaling (Anai et al. 2011, Pang et al. 2011a,b). Similarly, the LNCaP-LN3 orthotopic xenograft has been used to evaluate the response of bone metastasis to the antiVEGF receptor antibody DC101 (Sweeney et al. 2002).

The TRAMP model has been used to study angiogenic responses. Pathologically, the TRAMP mice with an FVB genetic background show highly vascularized tumors with early onset of angiogenic switch, together with a loss of E-cadherin expression, which is indicative of epithelialmesenchymal transition (Gingrich et al. 1999, KaplanLefko et al. 2003, Chiaverotti et al. 2008). Based on histological and immunohistochemical analysis, TRAMP mice tumors also showed high VEGF and FGF-2 expression, with increased microvessel density. Importantly, these mice recapitulate the stimulation of angiogenesis that has been observed in the aged mouse prostate, which is sensitive to treatment with antiangiogenic drugs (TNP-470 alone or in combination with SU5416) and finasteride (Montico et al. 2014). The role of VEGF in advanced PCa has also been studied in Pten-conditional knockout mice. PCa cells in these mice express the VEGF receptor NRP2 and activate signaling that leads to the expression of the Polycomb transcriptional repressor Bmi-1, which is implicated in the onset of PCa induced by Pten deletion (Goel et al. 2012). This highlights an important role of VEGF/NRP2 signaling in PCa and the need to develop new therapies that specifically target this pathway (Geretti et al. 2010).

\section{Anti-VEGF signaling therapies in the clinical management of $\mathrm{PCa}$}

High tumor VEGF levels have been associated with poor treatment outcomes in PCa, and higher VEGF serum levels have been described in patients with metastatic disease than in those with localized disease (Duque et al. 1999, Green et al. 2007). The use of anti-VEGF therapies in preclinical and clinical studies has been associated with increased side effects, including hypertension, gastrointestinal bleeding, intestinal perforation, and pulmonary embolism (Mangoni et al. 2012, Ogita et al. 2012). Although bevacizumab has shown some promise with improved progression-free survival, no significant improvement in overall survival has been achieved even in combination therapies (reviewed by Small \& Oh (2012) and Armstrong et al. (2013)). A newer anti-angiogenesis agent derived from the extracellular domains of the VEGFR (aflibercept) in combination with docetaxel and prednisone also offered no improvement in overall survival (Tannock et al. 2013). Yet given the comparative success of trials of newer agents that target VEGF signaling in other cancer types (Qi et al. 2011, Grothey et al. 2013), further studies are required of these agents in the PCa setting (Fig. 4). Indeed, cediranib, a VEGFR receptor tyrosine kinase inhibitor, was tested in a phase II trial on docetaxel pretreated CRPC patients as monotherapy and was found to be well tolerated, with some anti-tumor activity (Dahut et al. 2013). There are ongoing phase II trials using cediranib in combination with docetaxel plus prednisone or with abiraterone (ClinicalTrials.gov identifier NCT00527124 and NCT01574937 respectively) in hormone refractory PCa. A phase I trial that combines abiraterone with cabozantinib is also ongoing

Published by Bioscientifica Ltd 
(NCT01574937), as are a phase II trial that combines bevacizumab, lenalidomide, docetaxel, and prednisone for the treatment of metastatic CRPC (NCT00942578). Given the immunosuppressive and pro-angiogenic actions of VEGF, new combination therapies that target VEGF signaling and promote immune function are likely to emerge (reviewed by Cheng \& Fong (2014)). However, further studies are required to identify not only the optimal therapeutic combinations but also the sequencing of therapies with respect to cytotoxic chemotherapy use. This is of particular significance, given that the reduced tumor angiogenesis achieved by anti-VEGF therapies may impair optimal delivery of chemotherapeutics within tumor masses (Carmeliet \& Jain 2011).

\section{Effect of radiation therapy on angiogenesis}

Radiation therapy is an important treatment modality for the management of malignancies. Preclinical studies have demonstrated that in addition to inducing cell death, radiation also damages tumor vasculature and prevents tumor angiogenesis (El Kaffas et al. 2013). However, local treatment failures occur in many patients after the initial response to radiation therapy. Such recurrent diseases are noted to be more aggressive, to be more resistant to therapy, and to have poorer prognoses (Punnen et al. 2013). Recurrence has been partly attributed to subsequent improvements in the tumor vasculature being induced by radiation treatment. It has been reported that following radiation therapy, pro-angiogenic factors, including VEGF, are induced in the remaining malignant and stromal cells in the tumor. Mobilization of proangiogenic CD11b-positive myelomonocytic cells from the bone marrow to the tumor stroma has also been noted to improve the revascularization of the tumor bed (Martin (2013) and references therein). Thus, anti-VEGFs such as bevacizumab may both sensitize the tumor to radiotherapy and block post-therapy revascularization (Zhuang et al. 2014). However, the combination of radiation therapy with anti-VEGF therapies in PCa has not been extensively studied clinically. A phase II study reported by Vuky et al. (2012) examined long-term androgen suppression with bevacizumab and intensity-modulated radiation therapy in high-risk PCa with acute and late toxicity as endpoints. They reported that the addition of bevacizumab did not appear to worsen the effect of radiotherapy in PCa. A phase I trial that has recently completed recruitment is also studying the toxicity associated with the combination of sunitinib with hormone ablation and radiotherapy in patients with PCa (NCT00631529). More trials with overall survival as the endpoint are needed to assess the effect of combining anti-VEGFs with radiation therapy in prostate CRPC.

\section{Conclusion}

Tumors must exploit pro-angiogenesis pathways in order to metastasize. For this reason, targeting VEGF signaling remains an attractive approach to prevent, delay, or reverse tumor metastasis. The clinical utility of anti-angiogenesis therapy for metastatic PCa has been disappointing to date. Such therapies have almost exclusively targeted circulating VEGF or the tyrosine kinase activity of VEGF receptors. However, recent advances in understanding the regulation of VEGF in prostate cells (Kashyap et al. 2013) raises the potential to pharmacologically target the epigenetic complexes involved in the hormonal regulation of VEGF expression. Indeed, with the approval of the HDAC inhibitors vorinostat (SAHA) and romidepsin for the treatment of cutaneous T-cell lymphoma and with the ongoing trials of epigenetic targeted therapies for PCa (Campbell \& Tummino 2014), the simultaneous targeting of pro-androgenic, pro-estrogenic, and pro-angiogenic pathways with small molecular inhibitors of nuclear receptor coregulators is becoming an increasingly attractive approach.

\section{Declaration of interest}

The authors declare that there is no conflict of interest that could be perceived as prejudicing the impartiality of the review.

\section{Funding}

The authors acknowledge the financial support of the University of Nottingham, BBSRC, Cancer Research UK, and the Swedish Foundation for International Cooperation in Research and Higher Education.

\section{References}

Ahmed A, Ali S \& Sarkar FH 2014 Advances in androgen receptor targeted therapy for prostate cancer. Journal of Cellular Physiology 229 271-276. (doi:10.1002/jcp.24456)

Akiri G, Nahari D, Finkelstein Y, Le SY, Elroy-Stein O \& Levi BZ 1998 Regulation of vascular endothelial growth factor (VEGF) expression is mediated by internal initiation of translation and alternative initiation of transcription. Oncogene 17 227-236. (doi:10.1038/sj.onc.1202019)

Anai S, Sakamoto N, Sakai Y, Tanaka M, Porvasnik S, Urbanek C, Cao W, Goodison S \& Rosser CJ 2011 Dual targeting of Bcl-2 and VEGF: a potential strategy to improve therapy for prostate cancer. Urologic Oncology 29 421-429. (doi:10.1016/j.urolonc.2009.04.009)

Arcondeguy T, Lacazette E, Millevoi S, Prats H \& Touriol C 2013 VEGF-A mRNA processing, stability and translation: a paradigm for intricate regulation of gene expression at the post-transcriptional level. Nucleic Acids Research 41 7997-8010. (doi:10.1093/nar/gkt539)

Published by Bioscientifica Ltd 
Armstrong AJ, Haggman M, Stadler WM, Gingrich JR, Assikis V, Polikoff J, Damber JE, Belkoff L, Nordle O, Forsberg G et al. 2013 Long-term survival and biomarker correlates of tasquinimod efficacy in a multicenter randomized study of men with minimally symptomatic metastatic castration-resistant prostate cancer. Clinical Cancer Research 19 6891-6901. (doi:10.1158/1078-0432.CCR-13-1581)

Asangani IA, Dommeti VL, Wang X, Malik R, Cieslik M, Yang R, Escara-Wilke J, Wilder-Romans K, Dhanireddy S, Engelke C et al. 2014 Therapeutic targeting of BET bromodomain proteins in castration-resistant prostate cancer. Nature 510 278-282. (doi:10.1038/nature13229)

Auboeuf D, Honig A, Berget SM \& O’Malley BW 2002 Coordinate regulation of transcription and splicing by steroid receptor coregulators. Science 298 416-419. (doi:10.1126/science.1073734)

Auboeuf D, Dowhan DH, Kang YK, Larkin K, LeeJW, Berget SM \& O’Malley BW 2004 Differential recruitment of nuclear receptor coactivators may determine alternative RNA splice site choice in target genes. PNAS 101 2270-2274. (doi:10.1073/pnas.0308133100)

Baca SC, Prandi D, Lawrence MS, Mosquera JM, Romanel A, Drier Y, Park K, Kitabayashi N, MacDonald TY, Ghandi M et al. 2013 Punctuated evolution of prostate cancer genomes. Cell 153 666-677. (doi:10.1016/ j.cell.2013.03.021)

Barbieri CE, Baca SC, Lawrence MS, Demichelis F, Blattner M, Theurillat JP, White TA, Stojanov P, Van Allen E, Stransky N et al. 2012 Exome sequencing identifies recurrent SPOP, FOXA1 and MED12 mutations in prostate cancer. Nature Genetics 44 685-689. (doi:10.1038/ng.2279)

Barbieri CE, Bangma CH, Bjartell A, Catto JW, Culig Z, Gronberg H, Luo J, Visakorpi T \& Rubin MA 2013 The mutational landscape of prostate cancer. European Urology 64 567-576. (doi:10.1016/j.eururo.2013.05. 029)

Bates DO, Cui DG, Doughty JM, Winkler M, Sugiono M, Shields JD, Peat D, Gillatt D \& Harper SJ 2002 VEGF165b, an inhibitory splice variant of vascular endothelial growth factor, is down-regulated in renal cell carcinoma. Cancer Research 62 4123-4131.

Beltran H, Rickman DS, Park K, Chae SS, Sboner A, MacDonald TY, Wang Y, Sheikh KL, Terry S, Tagawa ST et al. 2011 Molecular characterization of neuroendocrine prostate cancer and identification of new drug targets. Cancer Discovery 1 487-495. (doi:10.1158/2159-8290.CD-11-0130)

Berger MF, Lawrence MS, Demichelis F, Drier Y, Cibulskis K, Sivachenko AY, Sboner A, Esgueva R, Pflueger D, Sougnez C et al. 2011 The genomic complexity of primary human prostate cancer. Nature 470 214-220. (doi:10.1038/nature09744)

Berman-Booty LD \& Knudsen KE 2015 Models of neuroendocrine prostate cancer. Endocrine-Related Cancer 22 R33-R49. (doi:10.1530/ERC-14-0393)

Boll K, Reiche K, Kasack K, Morbt N, Kretzschmar AK, Tomm JM, Verhaegh G, Schalken J, von Bergen M, Horn F et al. 2013 MiR-130a, miR-203 and miR-205 jointly repress key oncogenic pathways and are downregulated in prostate carcinoma. Oncogene 32 277-285. (doi:10.1038/ onc.2012.55)

de Bono JS, Logothetis CJ, Molina A, Fizazi K, North S, Chu L, Chi KN, Jones RJ, Goodman OB Jr, Saad F et al. 2011 Abiraterone and increased survival in metastatic prostate cancer. New England Journal of Medicine 364 1995-2005. (doi:10.1056/NEJMoa1014618)

Boorjian SA, Eastham JA, Graefen M, Guillonneau B, Karnes RJ, Moul JW, Schaeffer EM, Stief C \& Zorn KC 2012 A critical analysis of the long-term impact of radical prostatectomy on cancer control and function outcomes. European Urology 61 664-675. (doi:10.1016/j.eururo.2011.11.053)

Burton JB, Priceman SJ, Sung JL, Brakenhielm E, An DS, Pytowski B, Alitalo K $\&$ Wu L 2008 Suppression of prostate cancer nodal and systemic metastasis by blockade of the lymphangiogenic axis. Cancer Research 68 7828-7837. (doi:10.1158/0008-5472.CAN-08-1488)

Buteau-Lozano H, Ancelin M, Lardeux B, Milanini J \& Perrot-Applanat M 2002 Transcriptional regulation of vascular endothelial growth factor by estradiol and tamoxifen in breast cancer cells: a complex interplay between estrogen receptors $\alpha$ and $\beta$. Cancer Research 62 4977-4984.

Cai C, He HH, Chen S, Coleman I, Wang H, Fang Z, Nelson PS, Liu XS, Brown M \& Balk SP 2011 Androgen receptor gene expression in prostate cancer is directly suppressed by the androgen receptor through recruitment of lysine-specific demethylase 1. Cancer Cell 20 457-471. (doi:10.1016/j.ccr.2011.09.001)

Cai C, He HH, Gao S, Chen S, Yu Z, Gao Y, Chen MW, Zhang J, Ahmed M, Wang Y et al. 2014 Lysine-specific demethylase 1 has dual functions as a major regulator of androgen receptor transcriptional activity. Cell Reports 9 1618-1627. (doi:10.1016/j.celrep.2014.11.008)

Campbell RM \& Tummino PJ 2014 Cancer epigenetics drug discovery and development: the challenge of hitting the mark. Journal of Clinical Investigation 124 64-69. (doi:10.1172/JCI71605)

Cardus A, Panizo S, Encinas M, Dolcet X, Gallego C, Aldea M, Fernandez E \& Valdivielso JM 2009 1,25-dihydroxyvitamin D3 regulates VEGF production through a vitamin $\mathrm{D}$ response element in the VEGF promoter. Atherosclerosis 204 85-89. (doi:10.1016/j.atherosclerosis. 2008.08.020)

Carmeliet P \& Jain RK 2011 Molecular mechanisms and clinical applications of angiogenesis. Nature 473 298-307. (doi:10.1038/nature10144)

Carter HB, Albertsen PC, Barry MJ, Etzioni R, Freedland SJ, Greene KL, Holmberg L, Kantoff P, Konety BR, Murad MH et al. 2013 Early detection of prostate cancer: AUA Guideline. Journal of Urology 190 419-426. (doi:10.1016/j.juro.2013.04.119)

Cash J, Korchnak A, Gorman J, Tandon Y \& Fraizer G 2007 VEGF transcription and mRNA stability are altered by WT1 not DDS(R384W) expression in LNCaP cells. Oncology Reports 17 1413-1419.

Chakravarty D, Sboner A, Nair SS, Giannopoulou E, Li R, Hennig S, Mosquera JM, Pauwels J, Park K, Kossai M et al. 2014 The oestrogen receptor $\alpha$-regulated lncRNA NEAT1 is a critical modulator of prostate cancer. Nature Communications 5 5383. (doi:10.1038/ncomms6383)

Chang SH, Lu YC, Li X, Hsieh WY, Xiong Y, Ghosh M, Evans T, Elemento O \& Hla T 2013 Antagonistic function of the RNA-binding protein HuR and miR-200b in post-transcriptional regulation of vascular endothelial growth factor-A expression and angiogenesis. Journal of Biological Chemistry 288 4908-4921. (doi:10.1074/jbc.M112.423871)

Chen J, De S, Brainard J \& Byzova TV 2004 Metastatic properties of prostate cancer cells are controlled by VEGF. Cell Communication \& Adhesion 11 1-11. (doi:10.1080/15419060490471739)

Cheng X \& Blumenthal RM 2010 Coordinated chromatin control: structural and functional linkage of DNA and histone methylation. Biochemistry 49 2999-3008. (doi:10.1021/bi100213t)

Cheng ML \& Fong L 2014 Beyond sipuleucel-T: immune approaches to treating prostate cancer. Current Treatment Options in Oncology 15 115-126. (doi:10.1007/s11864-013-0267-z)

Chiaverotti T, Couto SS, Donjacour A, Mao JH, Nagase H, Cardiff RD, Cunha GR \& Balmain A 2008 Dissociation of epithelial and neuroendocrine carcinoma lineages in the transgenic adenocarcinoma of mouse prostate model of prostate cancer. American Journal of Pathology 172 236-246. (doi:10.2353/ajpath.2008.070602)

Claffey KP, Shih SC, Mullen A, Dziennis S, Cusick JL, Abrams KR, Lee SW \& Detmar M 1998 Identification of a human VPF/VEGF 3' untranslated region mediating hypoxia-induced mRNA stability. Molecular Biology of the Cell 9 469-481. (doi:10.1091/mbc.9.2.469)

Cohen T, Nahari D, Cerem LW, Neufeld G \& Levi BZ 1996 Interleukin 6 induces the expression of vascular endothelial growth factor. Journal of Biological Chemistry 271 736-741. (doi:10.1074/jbc.271.2.736)

Coles LS, Bartley MA, Bert A, Hunter J, Polyak S, Diamond P, Vadas MA \& Goodall GJ 2004 A multi-protein complex containing cold shock domain (Y-box) and polypyrimidine tract binding proteins forms on the vascular endothelial growth factor mRNA. Potential role in mRNA stabilization. European Journal of Biochemistry 271 648-660. (doi:10.1111/j.1432-1033.2003.03968.x)

Cuzick J, Thorat MA, Andriole G, Brawley OW, Brown PH, Culig Z, Eeles RA, Ford LG, Hamdy FC, Holmberg L et al. 2014 Prevention and early detection of prostate cancer. Lancet. Oncology 15 e484-e492. (doi:10.1016/S1470-2045(14)70211-6)

Dadiani M, Seger D, Kreizman T, Badikhi D, Margalit R, Eilam R \& Degani H 2009 Estrogen regulation of vascular endothelial growth factor in breast 
cancer in vitro and in vivo: the role of estrogen receptor $\alpha$ and c-Myc. Endocrine-Related Cancer 16 819-834. (doi:10.1677/ERC-08-0249)

Daehlin L, Damber JE, Selstam G \& Bergman B 1985 Testosterone-induced decrement of prostatic vascular resistance in rats is reversed by estrogens. Prostate 6 351-359. (doi:10.1002/pros.2990060404)

Dahut WL, Madan RA, Karakunnel JJ, Adelberg D, Gulley JL, Turkbey IB, Chau CH, Spencer SD, Mulquin M, Wright J et al. 2013 Phase II clinical trial of cediranib in patients with metastatic castration-resistant prostate cancer. BJU International 111 1269-1280. (doi:10.1111/ j.1464-410X.2012.11667.x)

Dai J, Kitagawa Y, Zhang J, Yao Z, Mizokami A, Cheng S, Nor J, McCauley LK, Taichman RS \& Keller ET 2004 Vascular endothelial growth factor contributes to the prostate cancer-induced osteoblast differentiation mediated by bone morphogenetic protein. Cancer Research 64 994-999. (doi:10.1158/0008-5472.CAN-03-1382)

Dawson MA \& Kouzarides T 2012 Cancer epigenetics: from mechanism to therapy. Cell 150 12-27. (doi:10.1016/j.cell.2012.06.013)

Debes JD, Sebo TJ, Lohse CM, Murphy LM, Haugen DA \& Tindall DJ 2003 p300 in prostate cancer proliferation and progression. Cancer Research 63 7638-7640.

Dibbens JA, Miller DL, Damert A, Risau W, Vadas MA \& Goodall GJ 1999 Hypoxic regulation of vascular endothelial growth factor mRNA stability requires the cooperation of multiple RNA elements. Molecular Biology of the Cell 10 907-919. (doi:10.1091/mbc.10.4.907)

Draisma G, Etzioni R, Tsodikov A, Mariotto A, Wever E, Gulati R, Feuer E \& de Koning H 2009 Lead time and overdiagnosis in prostate-specific antigen screening: importance of methods and context. Journal of the National Cancer Institute 101 374-383. (doi:10.1093/jnci/djp001)

Duque JL, Loughlin KR, Adam RM, Kantoff PW, Zurakowski D \& Freeman MR 1999 Plasma levels of vascular endothelial growth factor are increased in patients with metastatic prostate cancer. Urology 54 523-527. (doi:10.1016/S0090-4295(99)00167-3)

Eisermann K, Broderick CJ, Bazarov A, Moazam MM \& Fraizer GC 2013 Androgen up-regulates vascular endothelial growth factor expression in prostate cancer cells via an Sp1 binding site. Molecular Cancer 127. (doi:10.1186/1476-4598-12-7)

El Kaffas A, Giles A \& Czarnota GJ 2013 Dose-dependent response of tumor vasculature to radiation therapy in combination with Sunitinib depicted by three-dimensional high-frequency power Doppler ultrasound. Angiogenesis 16 443-454. (doi:10.1007/s10456-012-9329-2)

Eswaraka J, Giddabasappa A, Han G, Lalwani K, Eisele K, Feng Z, Affolter T, Christensen J \& Li G 2014 Axitinib and crizotinib combination therapy inhibits bone loss in a mouse model of castration resistant prostate cancer. BMC Cancer 14 742. (doi:10.1186/1471-2407-14-742)

Fan L, Wu Q, Xing X, Wei Y \& Shao Z 2012 MicroRNA-145 targets vascular endothelial growth factor and inhibits invasion and metastasis of osteosarcoma cells. Acta Biochimica et Biophysica Sinica 44 407-414. (doi:10.1093/abbs/gms019)

Fellows A, Griffin ME, Petrella BL, Zhong L, Parvin-Nejad FP, Fava R, Morganelli P, Robey RB \& Nichols RC 2012 AUF1/hnRNP D represses expression of VEGF in macrophages. Molecular Biology of the Cell 23 1414-1422. (doi:10.1091/mbc.E11-06-0545)

Ferlay J, Steliarova-Foucher E, Lortet-Tieulent J, Rosso S, Coebergh JW, Comber H, Forman D \& Bray F 2013 Cancer incidence and mortality patterns in Europe: estimates for 40 countries in 2012. European Journal of Cancer 49 1374-1403. (doi:10.1016/j.ejca.2012.12.027)

Folkman J 1971 Tumor angiogenesis: therapeutic implications. New England Journal of Medicine 285 1182-1186. (doi:10.1056/ NEJM197108122850711)

Folkman J, Merler E, Abernathy C \& Williams G 1971 Isolation of a tumor factor responsible for angiogenesis. Journal of Experimental Medicine 133 275-288. (doi:10.1084/jem.133.2.275)

Forsythe JA, Jiang BH, Iyer NV, Agani F, Leung SW, Koos RD \& Semenza GL 1996 Activation of vascular endothelial growth factor gene transcription by hypoxia-inducible factor 1 . Molecular and Cellular Biology 16 4604-4613.
Gabrilovich DI, Chen HL, Girgis KR, Cunningham HT, Meny GM, Nadaf S, Kavanaugh D \& Carbone DP 1996 Production of vascular endothelial growth factor by human tumors inhibits the functional maturation of dendritic cells. Nature Medicine 2 1096-1103. (doi:10.1038/ nm1096-1096)

Geretti E, van Meeteren LA, Shimizu A, Dudley AC, Claesson-Welsh L \& Klagsbrun M 2010 A mutated soluble neuropilin-2 B domain antagonizes vascular endothelial growth factor bioactivity and inhibits tumor progression. Molecular Cancer Research 8 1063-1073. (doi:10.1158/1541-7786.MCR-10-0157)

Gingrich JR, Barrios RJ, Morton RA, Boyce BF, DeMayo FJ, Finegold MJ, Angelopoulou R, Rosen JM \& Greenberg NM 1996 Metastatic prostate cancer in a transgenic mouse. Cancer Research 56 4096-4102.

Gingrich JR, Barrios RJ, Kattan MW, Nahm HS, Finegold MJ \& Greenberg NM 1997 Androgen-independent prostate cancer progression in the TRAMP model. Cancer Research 57 4687-4691.

Gingrich JR, Barrios RJ, Foster BA \& Greenberg NM 1999 Pathologic progression of autochthonous prostate cancer in the TRAMP model. Prostate Cancer and Prostatic Diseases 2 70-75. (doi:10.1038/sj.pcan. 4500296)

Godoy A, Montecinos VP, Gray DR, Sotomayor P, Yau JM, Vethanayagam RR, Singh S, Mohler JL \& Smith GJ 2011 Androgen deprivation induces rapid involution and recovery of human prostate vasculature. American Journal of Physiology. Endocrinology and Metabolism 300 E263-E275. (doi:10.1152/ajpendo.00210.2010)

Goel HL, Chang C, Pursell B, Leav I, Lyle S, Xi HS, Hsieh CC, Adisetiyo H, Roy-Burman P, Coleman IM et al. 2012 VEGF/neuropilin-2 regulation of Bmi-1 and consequent repression of IGF-IR define a novel mechanism of aggressive prostate cancer. Cancer Discovery 2 906-921. (doi:10.1158/2159-8290.CD-12-0085)

Goldberg-Cohen I, Furneauxb H \& Levy AP 2002 A 40-bp RNA element that mediates stabilization of vascular endothelial growth factor mRNA by HuR. Journal of Biological Chemistry 277 13635-13640. (doi:10.1074/jbc. M108703200)

Grabowska MM, DeGraff DJ, Yu X, Jin RJ, Chen Z, Borowsky AD \& Matusik RJ 2014 Mouse models of prostate cancer: picking the best model for the question. Cancer Metastasis Reviews 33 377-397. (doi:10.1007/ s10555-013-9487-8)

Gray DR, Huss WJ, Yau JM, Durham LE, Werdin ES, Funkhouser WK \& Smith GJ 2004 Short-term human prostate primary xenografts an in vivo model of human prostate cancer vasculature and angiogenesis. Cancer Research 64 1712-1721. (doi:10.1158/0008-5472.CAN-03-2700)

Gray MJ, Zhang J, Ellis LM, Semenza GL, Evans DB, Watowich SS \& Gallick GE 2005 HIF- $1 \alpha$, STAT3, CBP/p300 and Ref-1/APE are components of a transcriptional complex that regulates Src-dependent hypoxia-induced expression of VEGF in pancreatic and prostate carcinomas. Oncogene 24 3110-3120. (doi:10.1038/sj.onc.1208513)

Green MM, Hiley CT, Shanks JH, Bottomley IC, West CM, Cowan RA \& Stratford IJ 2007 Expression of vascular endothelial growth factor (VEGF) in locally invasive prostate cancer is prognostic for radiotherapy outcome. International Journal of Radiation Oncology, Biology, Physics 67 84-90. (doi:10.1016/j.ijrobp.2006.08.077)

Grothey A, Van Cutsem E, Sobrero A, Siena S, Falcone A, Ychou M, Humblet Y, Bouche O, Mineur L, Barone C et al. 2013 Regorafenib monotherapy for previously treated metastatic colorectal cancer (CORRECT): an international, multicentre, randomised, placebo-controlled, phase 3 trial. Lancet 381 303-312. (doi:10.1016/S0140-6736(12)61900-X)

Hamdollah Zadeh MA, Amin EM, Hoareau-Aveilla C, Domingo E, Symonds KE, Ye X, Heesom KJ, Salmon A, D'Silva O \& Betteridge KB 2015 Alternative splicing of TIA-1 in human colon cancer regulates VEGF isoform expression, angiogenesis, tumour growth and bevacizumab resistance. Molecular Oncology 9 167-178. (doi:10.1016/j.molonc.2014.07.017)

Harper SJ \& Bates DO 2008 VEGF-A splicing: the key to anti-angiogenic therapeutics? Nature Reviews. Cancer 8 880-887. (doi:10.1038/nrc2505)

Heemers HV, Sebo TJ, Debes JD, Regan KM, Raclaw KA, Murphy LM, Hobisch A, Culig Z \& Tindall DJ 2007 Androgen deprivation increases

Published by Bioscientifica Ltd 
p300 expression in prostate cancer cells. Cancer Research 67 3422-3430. (doi:10.1158/0008-5472.CAN-06-2836)

Heidenreich A, Abrahamsson PA, Artibani W, Catto J, Montorsi F, Van Poppel H, Wirth M \& Mottet N 2013 Early detection of prostate cancer: European Association of Urology recommendation. European Urology 64 347-354. (doi:10.1016/j.eururo.2013.06.051)

Heidenreich A, Bastian PJ, Bellmunt J, Bolla M, Joniau S, van der Kwast T, Mason M, Matveev V, Wiegel T, Zattoni F et al. 2014 EAU guidelines on prostate cancer. part 1: screening, diagnosis, and local treatment with curative intent-update 2013. European Urology 65 124-137.

(doi:10.1016/j.eururo.2013.09.046)

Horoszewicz JS, Leong SS, Chu TM, Wajsman ZL, Friedman M, Papsidero L, Kim U, Chai LS, Kakati S, Arya SK et al. 1980 The LNCaP cell line-a new model for studies on human prostatic carcinoma. Progress in Clinical and Biological Research 37 115-132.

Hrouda D, Nicol DL \& Gardiner RA 2003 The role of angiogenesis in prostate development and the pathogenesis of prostate cancer. Urological Research 30 347-355. (doi:10.1007/s00240-002-0287-9)

Huez I, Creancier L, Audigier S, Gensac MC, Prats AC \& Prats H 1998 Two independent internal ribosome entry sites are involved in translation initiation of vascular endothelial growth factor mRNA. Molecular and Cellular Biology 18 6178-6190.

Huggins C \& Hodges C 1941 Studies on prostatic cancer. I. The effect of castration, of estrogen and of androgen injection on serum phosphatases in metastatic carcinoma of the prostate. Cancer Research $1293-297$.

Humphrey PA 2012 Histological variants of prostatic carcinoma and their significance. Histopathology 60 59-74. (doi:10.1111/j.1365-2559. 2011.04039.x)

Huntzinger E \& Izaurralde E 2011 Gene silencing by microRNAs: contributions of translational repression and mRNA decay. Nature Reviews. Genetics 12 99-110. (doi:10.1038/nrg2936)

Ikeda E, Achen MG, Breier G \& Risau W 1995 Hypoxia-induced transcriptional activation and increased mRNA stability of vascular endothelial growth factor in C6 glioma cells. Journal of Biological Chemistry 270 19761-19766. (doi:10.1074/jbc.270.34.19761)

Jang SK, Krausslich HG, Nicklin MJ, Duke GM, Palmenberg AC \& Wimmer E 1988 A segment of the $5^{\prime}$ nontranslated region of encephalomyocarditis virus RNA directs internal entry of ribosomes during in vitro translation. Journal of Virology 62 2636-2643.

Kahl P, Gullotti L, Heukamp LC, Wolf S, Friedrichs N, Vorreuther R, Solleder G, Bastian PJ, Ellinger J, Metzger E et al. 2006 Androgen receptor coactivators lysine-specific histone demethylase 1 and four and a half LIM domain protein 2 predict risk of prostate cancer recurrence. Cancer Research 66 11341-11347. (doi:10.1158/0008-5472.CAN06-1570)

Kaighn ME, Narayan KS, Ohnuki Y, Lechner JF \& Jones LW 1979 Establishment and characterization of a human prostatic carcinoma cell line (PC-3). Investigative Urology 17 16-23.

Kaplan RN, Riba RD, Zacharoulis S, Bramley AH, Vincent L, Costa C, MacDonald DD, Jin DK, Shido K, Kerns SA et al. 2005 VEGFR1-positive haematopoietic bone marrow progenitors initiate the pre-metastatic niche. Nature 438 820-827. (doi:10.1038/nature04186)

Kaplan-Lefko PJ, Chen TM, Ittmann MM, Barrios RJ, Ayala GE, Huss WJ, Maddison LA, Foster BA \& Greenberg NM 2003 Pathobiology of autochthonous prostate cancer in a pre-clinical transgenic mouse model. Prostate 55 219-237. (doi:10.1002/pros.10215)

Kashyap V, Ahmad S, Nilsson EM, Helczynski L, Kenna S, Persson JL, Gudas LJ \& Mongan NP 2013 The lysine specific demethylase-1 (LSD1/KDM1A) regulates VEGF-A expression in prostate cancer. Molecular Oncology 7 555-566. (doi:10.1016/j.molonc.2013.01.003)

Kaur S, Chang T, Singh SP, Lim L, Mannan P, Garfield SH, Pendrak ML, Soto-Pantoja DR, Rosenberg AZ, Jin S et al. 2014 CD47 signaling regulates the immunosuppressive activity of VEGF in T cells. Journal of Immunology 193 3914-3924. (doi:10.4049/jimmunol.1303116)
King PH 2000 RNA-binding analyses of HuC and HuD with the VEGF and c-myc 3 '-untranslated regions using a novel ELISA-based assay. Nucleic Acids Research 28 E20. (doi:10.1093/nar/28.7.e20)

Kitagawa Y, Dai J, Zhang J, Keller JM, Nor J, Yao Z \& Keller ET 2005 Vascular endothelial growth factor contributes to prostate cancer-mediated osteoblastic activity. Cancer Research 65 10921-10929. (doi:10.1158/ 0008-5472.CAN-05-1809)

Klezovitch O, Chevillet J, Mirosevich J, Roberts RL, Matusik RJ \& Vasioukhin V 2004 Hepsin promotes prostate cancer progression and metastasis. Cancer Cell 6 185-195. (doi:10.1016/j.ccr.2004.07.008)

Kooistra SM \& Helin K 2012 Molecular mechanisms and potential functions of histone demethylases. Nature Reviews. Molecular Cell Biology 13 297-311. (doi:10.1038/nrm3327)

Krejsgaard T, Vetter-Kauczok CS, Woetmann A, Lovato P, Labuda T, Eriksen KW, Zhang Q, Becker JC \& Odum N 2006 Jak3- and JNK-dependent vascular endothelial growth factor expression in cutaneous T-cell lymphoma. Leukemia 20 1759-1766. (doi:10.1038/sj.leu.2404350)

Lambrechts D, Storkebaum E, Morimoto M, Del-Favero J, Desmet F, Marklund SL, Wyns S, Thijs V, Andersson J, van Marion I et al. 2003 VEGF is a modifier of amyotrophic lateral sclerosis in mice and humans and protects motoneurons against ischemic death. Nature Genetics $\mathbf{3 4}$ 383-394. (doi:10.1038/ng1211)

Levy AP, Levy NS \& Goldberg MA 1996 Post-transcriptional regulation of vascular endothelial growth factor by hypoxia. Journal of Biological Chemistry 271 2746-2753. (doi:10.1074/jbc.271.5.2746)

Lorente D \& De Bono JS 2014 Molecular alterations and emerging targets in castration resistant prostate cancer. European Journal of Cancer $\mathbf{5 0}$ 753-764. (doi:10.1016/j.ejca.2013.12.004)

Maes C, Kobayashi T, Selig MK, Torrekens S, Roth SI, Mackem S, Carmeliet G \& Kronenberg HM 2010 Osteoblast precursors, but not mature osteoblasts, move into developing and fractured bones along with invading blood vessels. Developmental Cell 19 329-344. (doi:10.1016/ j.devcel.2010.07.010)

Mangoni M, Vozenin MC, Biti G \& Deutsch E 2012 Normal tissues toxicities triggered by combined anti-angiogenic and radiation therapies: hurdles might be ahead. British Journal of Cancer 107 308-314. (doi:10.1038/ bjc.2012.236)

Martin BJ 2013 Inhibiting vasculogenesis after radiation: a new paradigm to improve local control by radiotherapy. Seminars in Radiation Oncology 23 281-287. (doi:10.1016/j.semradonc.2013.05.002)

Masumori N, Thomas TZ, Chaurand P, Case T, Paul M, Kasper S, Caprioli RM, Tsukamoto T, Shappell SB \& Matusik RJ 2001 A probasin-large T antigen transgenic mouse line develops prostate adenocarcinoma and neuroendocrine carcinoma with metastatic potential. Cancer Research 61 2239-2249.

Mavrou A, Brakspear K, Hamdollah-Zadeh M, Damodaran G, Babaei-Jadidi R, Oxley J, Gillatt DA, Ladomery MR, Harper SJ, Bates DO et al. 2014 Serine-arginine protein kinase 1 (SRPK1) inhibition as a potential novel targeted therapeutic strategy in prostate cancer. Oncogene [in press]. (doi:10.1038/onc.2014.360)

Mellman I, Coukos G \& Dranoff G 2011 Cancer immunotherapy comes of age. Nature 480 480-489. (doi:10.1038/nature10673)

Metzger E, Wissmann M, Yin N, Muller JM, Schneider R, Peters AH, Gunther T, Buettner R \& Schule R 2005 LSD1 demethylates repressive histone marks to promote androgen-receptor-dependent transcription. Nature 437 436-439. (doi:10.1038/nature04020)

Midy V \& Plouet J 1994 Vasculotropin/vascular endothelial growth factor induces differentiation in cultured osteoblasts. Biochemical and Biophysical Research Communications 199 380-386. (doi:10.1006/bbrc. 1994.1240)

Miller DL, Dibbens JA, Damert A, Risau W, Vadas MA \& Goodall GJ 1998 The vascular endothelial growth factor mRNA contains an internal ribosome entry site. FEBS Letters 434 417-420. (doi:10.1016/S00145793(98)01025-4)

Molife LR, Omlin A, Jones RJ, Karavasilis V, Bloomfield D, Lumsden G, Fong PC, Olmos D, O'Sullivan JM, Pedley I et al. 2014 Randomized

Published by Bioscientifica Ltd. 
phase II trial of nintedanib, afatinib and sequential combination in castration-resistant prostate cancer. Future Oncology 10 219-231. (doi:10.2217/fon.13.250)

Montecinos VP, Godoy A, Hinklin J, Vethanayagam RR \& Smith GJ 2012 Primary xenografts of human prostate tissue as a model to study angiogenesis induced by reactive stroma. PLOS ONE 7 e29623. (doi:10.1371/journal.pone.0029623)

Montico F, Kido LA, Hetzl AC \& Cagnon VH 2014 Prostatic angiogenic responses in late life: antiangiogenic therapy influences and relation with the glandular microenvironment in the transgenic adenocarcinoma of mouse prostate (TRAMP) model. Prostate 75 484-499. (doi:10.1002/pros.22934)

Morris MJ, Negishi Y, Pazsint C, Schonhoft JD \& Basu S 2010 An RNA G-quadruplex is essential for cap-independent translation initiation in human VEGF IRES. Journal of the American Chemical Society 132 17831-17839. (doi:10.1021/ja106287x)

Nowak DG, Woolard J, Amin EM, Konopatskaya O, Saleem MA, Churchill AJ, Ladomery MR, Harper SJ \& Bates DO 2008 Expression of pro- and antiangiogenic isoforms of VEGF is differentially regulated by splicing and growth factors. Journal of Cell Science 121 3487-3495. (doi:10.1242/jcs. 016410)

Nowak DG, Amin EM, Rennel ES, Hoareau-Aveilla C, Gammons M, Damodoran G, Hagiwara M, Harper SJ, Woolard J, Ladomery MR et al. 2010 Regulation of vascular endothelial growth factor (VEGF) splicing from pro-angiogenic to anti-angiogenic isoforms: a novel therapeutic strategy for angiogenesis. Journal of Biological Chemistry 285 5532-5540. (doi:10.1074/jbc.M109.074930)

Ogita S, Tejwani S, Heilbrun L, Fontana J, Heath E, Freeman S, Smith D, Baranowski K \& Vaishampayan U 2012 Pilot phase II trial of bevacizumab monotherapy in nonmetastatic castrate-resistant prostate cancer. ISRN Oncology 2012 242850. (doi:10.5402/2012/242850)

Oltean S, Gammons M, Hulse R, Hamdollah-Zadeh M, Mavrou A, Donaldson L, Salmon AH, Harper SJ, Ladomery MR \& Bates DO 2012 SRPK1 inhibition in vivo: modulation of VEGF splicing and potential treatment for multiple diseases. Biochemical Society Transactions 40 831-835. (doi:10.1042/BST20120051)

Onesto C, Berra E, Grepin R \& Pages G 2004 Poly(A)-binding proteininteracting protein 2, a strong regulator of vascular endothelial growth factor mRNA. Journal of Biological Chemistry 279 34217-34226. (doi:10.1074/jbc.M400219200)

Pang X, Wu Y, Wu Y, Lu B, Chen J, Wang J, Yi Z, Qu W \& Liu M 2011 ( (-)Gossypol suppresses the growth of human prostate cancer xenografts via modulating VEGF signaling-mediated angiogenesis. Molecular Cancer Therapeutics 10 795-805. (doi:10.1158/1535-7163.MCT10-0936)

Pang X, Zhang L, Lai L, Chen J, Wu Y, Yi Z, Zhang J, Qu W, Aggarwal BB \& Liu M $2011 b 1^{\prime}$-acetoxychavicol acetate suppresses angiogenesismediated human prostate tumor growth by targeting VEGF-mediated Src-FAK-Rho GTPase-signaling pathway. Carcinogenesis 32 904-912. (doi:10.1093/carcin/bgr052)

Pei Z, Lin D, Song X, Li H \& Yao H 2008 TLR4 signaling promotes the expression of VEGF and TGF $\beta 1$ in human prostate epithelial PC3 cells induced by lipopolysaccharide. Cellular Immunology 254 20-27. (doi:10.1016/j.cellimm.2008.06.007)

Pelletier J \& Sonenberg N 1988 Internal initiation of translation of eukaryotic mRNA directed by a sequence derived from poliovirus RNA. Nature 334 320-325. (doi:10.1038/334320a0)

Perillo B, Ombra MN, Bertoni A, Cuozzo C, Sacchetti S, Sasso A, Chiariotti L, Malorni A, Abbondanza C \& Avvedimento EV 2008 DNA oxidation as triggered by H3K9me2 demethylation drives estrogen-induced gene expression. Science 319 202-206. (doi:10.1126/science.1147674)

Pettaway CA, Pathak S, Greene G, Ramirez E, Wilson MR, Killion JJ \& Fidler JJ 1996 Selection of highly metastatic variants of different human prostatic carcinomas using orthotopic implantation in nude mice. Clinical Cancer Research 2 1627-1636.
Pinthus JH, Waks T, Schindler DG, Harmelin A, Said JW, Belldegrun A, Ramon J \& Eshhar Z 2000 WISH-PC2: a unique xenograft model of human prostatic small cell carcinoma. Cancer Research 60 6563-6567.

Porta C, Giglione P, Liguigli W \& Paglino C 2015 Dovitinib (CHIR258, TKI258): structure, development and preclinical and clinical activity. Future Oncology 11 39-50. (doi:10.2217/fon.14.208)

Presnell SC, Werdin ES, Maygarden S, Mohler JL \& Smith GJ 2001 Establishment of short-term primary human prostate xenografts for the study of prostate biology and cancer. American Journal of Pathology 159 855-860. (doi:10.1016/S0002-9440(10)61761-0)

Punnen S, Cooperberg MR, D'Amico AV, Karakiewicz PI, Moul JW, Scher HI, Schlomm T \& Freedland SJ 2013 Management of biochemical recurrence after primary treatment of prostate cancer: a systematic review of the literature. European Urology 64 905-915. (doi:10.1016/ j.eururo.2013.05.025)

Qi WX, Tang LN, He AN, Shen Z \& Yao Y 2011 The role of vandetanib in the second-line treatment for advanced non-small-cell-lung cancer: a metaanalysis of four randomized controlled trials. Lung 189 437-443. (doi:10.1007/s00408-011-9332-1)

Rahman MM, Miyamoto H, Lardy H \& Chang C 2003 Inactivation of androgen receptor coregulator ARA55 inhibits androgen receptor activity and agonist effect of antiandrogens in prostate cancer cells. PNAS 100 5124-5129. (doi:10.1073/pnas.0530097100)

Roskoski R Jr 2007 Vascular endothelial growth factor (VEGF) signaling in tumor progression. Critical Reviews in Oncology/Hematology 62 179-213. (doi:10.1016/j.critrevonc.2007.01.006)

Rotili D, Tomassi S, Conte M, Benedetti R, Tortorici M, Ciossani G, Valente S, Marrocco B, Labella D, Novellino E et al. 2014 Pan-histone demethylase inhibitors simultaneously targeting Jumonji $\mathrm{C}$ and lysine-specific demethylases display high anticancer activities. Journal of Medicinal Chemistry 57 42-55. (doi:10.1021/ jm4012802)

Scher HI, Fizazi K, Saad F, Taplin ME, Sternberg CN, Miller K, de Wit R, Mulders P, Chi KN, Shore ND et al. 2012 Increased survival with enzalutamide in prostate cancer after chemotherapy. New England Journal of Medicine 367 1187-1197. (doi:10.1056/ NEJMoa1207506)

Semenas J, Allegrucci C, Boorjian SA, Mongan NP \& Persson JL 2012 Overcoming drug resistance and treating advanced prostate cancer. Current Drug Targets 13 1308-1323. (doi:10.2174/1389450128 02429615)

Setlur SR, Mertz KD, Hoshida Y, Demichelis F, Lupien M, Perner S, Sboner A, Pawitan Y, Andren O, Johnson LA et al. 2008 Estrogen-dependent signaling in a molecularly distinct subclass of aggressive prostate cancer. Journal of the National Cancer Institute 100 815-825. (doi:10.1093/jnci/djn150)

Sfar S, Hassen E, Saad H, Mosbah F \& Chouchane L 2006 Association of VEGF genetic polymorphisms with prostate carcinoma risk and clinical outcome. Cytokine 35 21-28. (doi:10.1016/j.cyto.2006.07.003)

Shah RB, Mehra R, Chinnaiyan AM, Shen R, Ghosh D, Zhou M, Macvicar GR, Varambally S, Harwood J, Bismar TA et al. 2004 Androgen-independent prostate cancer is a heterogeneous group of diseases: lessons from a rapid autopsy program. Cancer Research 64 9209-9216. (doi:10.1158/0008-5472.CAN-04-2442)

Sharma NL, Massie CE, Ramos-Montoya A, Zecchini V, Scott HE, Lamb AD, MacArthur S, Stark R, Warren AY, Mills IG et al. 2013 The androgen receptor induces a distinct transcriptional program in castrationresistant prostate cancer in man. Cancer Cell 23 35-47. (doi:10.1016/ j.ccr.2012.11.010)

Shih SC \& Claffey KP 1999 Regulation of human vascular endothelial growth factor mRNA stability in hypoxia by heterogeneous nuclear ribonucleoprotein L. Journal of Biological Chemistry 274 1359-1365. (doi:10.1074/jbc.274.3.1359)

Shima DT, Deutsch U \& D'Amore PA 1995 Hypoxic induction of vascular endothelial growth factor (VEGF) in human epithelial cells is mediated

Published by Bioscientifica Ltd. 
by increases in mRNA stability. FEBS Letters 370 203-208. (doi:10.1016/ 0014-5793(95)00831-S)

Siegel RL, Miller KD \& Jemal A 2015 Cancer statistics, 2015. CA: A Cancer Journal for Clinicians 65 5-29. (doi:10.3322/caac.21254)

Small AC \& Oh WK 2012 Bevacizumab treatment of prostate cancer. Expert Opinion on Biological Therapy 12 1241-1249. (doi:10.1517/ 14712598.2012.704015)

Smith MR, Sweeney CJ, Corn PG, Rathkopf DE, Smith DC, Hussain M, George DJ, Higano CS, Harzstark AL, Sartor AO et al. 2014 Cabozantinib in chemotherapy-pretreated metastatic castration-resistant prostate cancer: results of a phase II nonrandomized expansion study. Journal of Clinical Oncology 32 3391-3399. (doi:10.1200/JCO. 2013.54.5954)

Sohn EJ, Won G, Lee J, Lee S \& Kim SH 2015 Upregulation of miRNA3195 and miRNA374b mediates the anti-angiogenic properties of melatonin in hypoxic PC-3 prostate cancer cells. Journal of Cancer 6 19-28. (doi:10.7150/jca.9591)

Sridhar SS, Joshua AM, Gregg R, Booth CM, Murray N, Golubovic J, Wang L, Harris P \& Chi KN 2014 A phase II study of GW786034 (pazopanib) with or without bicalutamide in patients with castration-resistant prostate cancer. Clinical Genitourinary Cancer 13 124-129. (doi:10.1016/j.clgc. 2014.06.001)

Sterling JA, Edwards JR, Martin TJ \& Mundy GR 2011 Advances in the biology of bone metastasis: how the skeleton affects tumor behavior. Bone 48 6-15. (doi:10.1016/j.bone.2010.07.015)

Stewart SB \& Boorjian SA 2014 Radical prostatectomy in high-risk and locally advanced prostate cancer: Mayo Clinic perspective. Urologic Oncology [in press]. (doi:10.1016/j.urolonc.2014.10.003)

Street J, Bao M, deGuzman L, Bunting S, Peale FV Jr, Ferrara N, Steinmetz H, Hoeffel J, Cleland JL, Daugherty A et al. 2002 Vascular endothelial growth factor stimulates bone repair by promoting angiogenesis and bone turnover. PNAS 99 9656-9661. (doi:10.1073/pnas.152324099)

Sweeney P, Karashima T, Kim SJ, Kedar D, Mian B, Huang S, Baker C, Fan Z, Hicklin DJ, Pettaway CA et al. 2002 Anti-vascular endothelial growth factor receptor 2 antibody reduces tumorigenicity and metastasis in orthotopic prostate cancer xenografts via induction of endothelial cell apoptosis and reduction of endothelial cell matrix metalloproteinase type 9 production. Clinical Cancer Research 8 2714-2724.

Szczyrba J, Loprich E, Wach S, Jung V, Unteregger G, Barth S, Grobholz R, Wieland W, Stohr R, Hartmann A et al. 2010 The microRNA profile of prostate carcinoma obtained by deep sequencing. Molecular Cancer Research 8 529-538. (doi:10.1158/1541-7786.MCR-09-0443)

Szczyrba J, Nolte E, Hart M, Doll C, Wach S, Taubert H, Keck B, Kremmer E, Stohr R, Hartmann A et al. 2013 Identification of ZNF217, hnRNP-K, VEGF-A and IPO7 as targets for microRNAs that are downregulated in prostate carcinoma. International Journal of Cancer 132 775-784. (doi:10.1002/ijc.27731)

Tannock IF, Fizazi K, Ivanov S, Karlsson CT, Flechon A, Skoneczna I, Orlandi F, Gravis G, Matveev V, Bavbek S et al. 2013 Aflibercept versus placebo in combination with docetaxel and prednisone for treatment of men with metastatic castration-resistant prostate cancer (VENICE): a phase 3, double-blind randomised trial. Lancet. Oncology 14 760-768. (doi:10.1016/S1470-2045(13)70184-0)

Tay Y, Zhang J, Thomson AM, Lim B \& Rigoutsos I 2008 MicroRNAs to Nanog, Oct 4 and Sox 2 coding regions modulate embryonic stem cell differentiation. Nature 455 1124-1128. (doi:10.1038/nature07299)

Thalmann GN, Anezinis PE, Chang SM, Zhau HE, Kim EE, Hopwood VL, Pathak S, von Eschenbach AC \& Chung LW 1994 Androgenindependent cancer progression and bone metastasis in the LNCaP model of human prostate cancer. Cancer Research 54 2577-2581.

Tombal B, Alcaraz A, James N, Valdagni R \& Irani J 2014 Can we improve the definition of high-risk, hormone naive, non-metastatic prostate cancer? BJU International 113 189-199. (doi:10.1111/bju. 12469)

Van Der Kelen K, Beyaert R, Inze D \& De Veylder L 2009 Translational control of eukaryotic gene expression. Critical Reviews in
Biochemistry and Molecular Biology 44 143-168. (doi:10.1080/ 10409230902882090)

Vuky J, Pham HT, Warren S, Douglass E, Badiozamani K, Madsen B, Hsi A \& Song G 2012 Phase II study of long-term androgen suppression with bevacizumab and intensity-modulated radiation therapy (IMRT) in high-risk prostate cancer. International Journal of Radiation Oncology, Biology, Physics 82 e609-e615. (doi:10.1016/j.ijrobp.2011. 09.002)

Walczak R, Joseph SB, Laffitte BA, Castrillo A, Pei L \& Tontonoz P 2004 Transcription of the vascular endothelial growth factor gene in macrophages is regulated by liver X receptors. Journal of Biological Chemistry 279 9905-9911. (doi:10.1074/jbc.M310587200)

Wan X, Corn PG, Yang J, Palanisamy N, Starbuck MW, Efstathiou E, Tapia EM, Zurita AJ, Aparicio A, Ravoori MK et al. 2014 Prostate cancer cell-stromal cell crosstalk via FGFR1 mediates antitumor activity of dovitinib in bone metastases. Science Translational Medicine 6 252ra122. (doi:10.1126/scitranslmed.3009332)

Wang S, Gao J, Lei Q, Rozengurt N, Pritchard C, Jiao J, Thomas GV, Li G, Roy-Burman P, Nelson PS et al. 2003 Prostate-specific deletion of the murine Pten tumor suppressor gene leads to metastatic prostate cancer. Cancer Cell 4 209-221. (doi:10.1016/S15356108(03)00215-0)

Wang Q, Li W, Zhang Y, Yuan X, Xu K, Yu J, Chen Z, Beroukhim R, Wang H, Lupien $\mathrm{M}$ et al. 2009 Androgen receptor regulates a distinct transcription program in androgen-independent prostate cancer. Cell 138 245-256. (doi:10.1016/j.cell.2009.04.056)

Wegiel B, Bjartell A, Ekberg J, Gadaleanu V, Brunhoff C \& Persson JL 2005 A role for cyclin A1 in mediating the autocrine expression of vascular endothelial growth factor in prostate cancer. Oncogene 24 6385-6393. (doi:10.1038/sj.onc.1208795)

Wegiel B, Bjartell A, Tuomela J, Dizeyi N, Tinzl M, Helczynski L, Nilsson E, Otterbein L, Härkönen P \& Persson JL 2008 Multiple cellular mechanisms related to cyclin A1 in prostate cancer invasion and metastasis. Journal of the National Cancer Institute 100 1022-1036. (doi:10.1093/jnci/djn214)

Weiner AB, Patel SG \& Eggener SE 2015 Pathologic outcomes for low-risk prostate cancer after delayed radical prostatectomy in the United States. Urologic Oncology 33 164.e11-164.e17. (doi:10.1016/j.urolonc. 2014.12.012)

Wong SY, Haack H, Crowley D, Barry M, Bronson RT \& Hynes RO 2005 Tumor-secreted vascular endothelial growth factor-C is necessary for prostate cancer lymphangiogenesis, but lymphangiogenesis is unnecessary for lymph node metastasis. Cancer Research 65 9789-9798. (doi:10.1158/0008-5472.CAN-05-0901)

Woolard J, Wang WY, Bevan HS, Qiu Y, Morbidelli L, Pritchard-Jones RO, Cui TG, Sugiono M, Waine E, Perrin R et al. 2004 VEGF165b, an inhibitory vascular endothelial growth factor splice variant: mechanism of action, in vivo effect on angiogenesis and endogenous protein expression. Cancer Research 64 7822-7835. (doi:10.1158/ 0008-5472.CAN-04-0934)

Wu J, Richer J, Horwitz KB \& Hyder SM 2004 Progestin-dependent induction of vascular endothelial growth factor in human breast cancer cells: preferential regulation by progesterone receptor B. Cancer Research 64 2238-2244. (doi:10.1158/0008-5472.CAN-03-3044)

Wu X, Gong S, Roy-Burman P, Lee P \& Culig Z 2013 Current mouse and cell models in prostate cancer research. Endocrine-Related Cancer 20 R155-R170. (doi:10.1530/ERC-12-0285)

Yonou H, Yokose T, Kamijo T, Kanomata N, Hasebe T, Nagai K, Hatano T, Ogawa Y \& Ochiai A 2001 Establishment of a novel species-and tissuespecific metastasis model of human prostate cancer in humanized nonobese diabetic/severe combined immunodeficient mice engrafted with human adult lung and bone. Cancer Research 61 2177-2182.

Yu J, Mani RS, Cao Q, Brenner CJ, Cao X, Wang X, Wu L, Li J, Hu M, Gong Y et al. 2010 An integrated network of androgen receptor, polycomb, and TMPRSS2-ERG gene fusions in prostate cancer progression. Cancer Cell 17 443-454. (doi:10.1016/j.ccr.2010.03.018) 
Yue X, Wang P, Xu J, Zhu Y, Sun G, Pang Q \& Tao R 2012 MicroRNA-205 functions as a tumor suppressor in human glioblastoma cells by targeting VEGF-A. Oncology Reports 27 1200-1206. (doi:10.3892/or.2011.1588)

Yun H, Lee M, Kim SS \& Ha J 2005 Glucose deprivation increases mRNA stability of vascular endothelial growth factor through activation of AMP-activated protein kinase in DU145 prostate carcinoma. Journal of Biological Chemistry 280 9963-9972. (doi:10.1074/jbc.M412994200)
Zhou Z, Flesken-Nikitin A, Corney DC, Wang W, Goodrich DW, Roy-Burman P \& Nikitin AY 2006 Synergy of p53 and Rb deficiency in a conditional mouse model for metastatic prostate cancer. Cancer Research 66 7889-7898. (doi:10.1158/0008-5472.CAN-06-0486)

Zhuang HQ, Yuan ZY \& Wang P 2014 Research progress on the mechanisms of combined bevacizumab and radiotherapy. Recent Patents on Anti-Cancer Drug Discovery 9 129-134.

Received in final form 25 March 2015

Accepted 1 April 2015

Made available online as an Accepted Preprint

13 April 2015
Published by Bioscientifica Ltd. 